\title{
TESTING FOR MARKET DISCIPLINE IN THE EUROPEAN BANKING INDUSTRY: EVIDENCE FROM SUBORDINATED DEBT ISSUES
}

\author{
Andrea Sironi*
}

July 2000

\begin{abstract}
The question of whether private investors can discriminate between the risk taken by banks is empirically investigated by testing the risk sensitivity of European banks' subordinated notes and debentures (SND) spreads. A unique dataset of spreads, ratings, accounting and market measures of bank risk is used for a sample of SND issued during the 1991-2000:Q1 period. Moody's Bank Financial Strength (MBFS) and FitchIBCA Individual (FII) ratings, which omit the influence of government and other external support on risk borne by investors, are found to perform better than accounting variables in explaining the variability of spreads. Empirical results support the hypothesis that SND investors are sensitive to bank risk, with the exception of SND issued by public banks, i.e. government owned or guaranteed institutions. Results also show that the risk sensitivity of SND spreads has improved during the nineties.
\end{abstract}

JEL Classification Numbers: G15, G21, G28

Keywords: Banks, bank regulation, market discipline, subordinated debt, credit ratings

\footnotetext{
* Associate Professor of Financial Markets and Institutions, Università Commerciale Luigi Bocconi, Via Sarfatti 25, 20136 Milano, Italy. Tel. -39-02-58365912. E-mail: andrea.sironi@uni-bocconi.it. The author wishes to thank Allen Berger, Mark Carey, Michael Gordy, Diana Hancock, William Lang, Gianni De Nicolò, Douglas Robertson and other participants in a Federal Reserve Board seminar in Washington for useful comments. This paper was prepared while the author was visiting the Federal Reserve Board. The views expressed in this paper are those of the author and do not necessarily reflect those of the Board of Governors, or members of its staff. All errors remain those of the author.
} 


\section{INTRODUCTION}

The ability of financial markets to discipline bank behavior by pricing their uninsured debt according to their risk profile has recently gathered significant attention as numerous proposals to introduce a mandatory subordinated debt policy have been drafted and critically discussed ${ }^{1}$. There are two interdependent reasons for this emphasis on market discipline. First, the activities of major international banks have become increasingly complex. As a consequence, the task of controlling their risk taking behaviors has become an increasingly difficult one. Second, a trend towards a stronger regulatory reliance on banks' own internal risk management systems has emerged. In its 1996 Capital Accord amendment proposal ${ }^{2}$, the Basel Committee on Banking Supervision endorsed the use of banks' own market risks internal models, contingent on important qualitative and quantitative standards. More recently, in an effort to reduce the incentive for regulatory capital arbitrage transactions prompted by the widening gap between banks' and regulators' definitions of credit risk capital, the Basel Committee has proposed to introduce an Internal Ratings Based (IRB) approach to capital requirements ${ }^{3}$. This proposal is in turn considered by many as a first step towards the use of full portfolio credit risk models to set regulatory capital.

A future capital adequacy regime based on banks' internal risk measurement models poses a major problem for bank supervisors. Indeed, given the shareholders' option-like payoff profile, banks experiencing significant unexpected losses and getting closer to their default point could find it convenient to adopt gaming behaviors by artificially reducing the internally produced risk measures while increasing their risk taking activities in an effort to replenish their equity capital. The growing independence of bank management in determining their capital adequacy must therefore be accompanied by an increasing role of market forces in monitoring banks' risk profiles.

The relevance of this role to be played by private investors has been recognized by the Basel Committee. The Committee's recent proposals to reform capital adequacy are based on three main "pillars". While the first two pillars focus on credit risk capital requirements and on the

\footnotetext{
${ }^{1}$ See Board of Governors of the Federal Reserve System (1999) for a review.

${ }^{2}$ See Basel Committee on Banking Supervision (1996).

${ }^{3}$ While the details of this proposal are not known yet, it is generally understood that risk weights would be set according to banks' internally produced estimates of default probability and loss given default. See Basel Committee on Banking Supervision (1999c).
} 
future role of national supervisors, the third pillar is aimed at strengthening the role of market discipline through an improvement in banks' disclosure ${ }^{4}$.

A key issue in the debate about market discipline concerns the extent to which private investors can observe and price the risk taken by banks and, ultimately, affect banks' management decisions. ${ }^{5}$ This study sheds light on these questions by examining whether private investors price European banks' SND issues according to the risk profile of the issuer. This is done by testing the statistical relationship between the primary market spreads of a sample of SND issued during 1991-2000 and alternative measures of bank risk.

Three main results emerge from the empirical analysis. First, SND investors appear to rationally discriminate between the different risk profiles of European banks. Second, the risk sensitivity of SND spreads has been increasing over time, suggesting that implicit guarantees such as TBTF policies were present in the first half of the nineties and became weaker or vanished during the second part of the decade. Third, European public banks benefit from a significant government subsidy, in the form of a lower cost of SND issues, the value of which has been increasing over time.

These results have important policy implications for the evaluation of three main issues: (1) the extent to which market discipline can supplement regulatory discipline, (2) the effectiveness of a mandatory subordinated debt policy in strengthening direct market discipline, (3) the value of the implicit interest rate government subsidy received by European public banks ${ }^{6}$.

This paper proceeds as follows. Section 2 reviews the main empirical studies on the role of SND in and highlights the contribution of this paper. Section 3 presents the methodology of the empirical analysis. Section 4 describes the data sources and summarizes sample characteristics. Section 5 presents the empirical results. Section 6 concludes.

\section{Previous eVidence}

Two generations of empirical studies of the role of SND in market discipline have appeared previously. The first generation was aimed at testing whether private investors can rationally

\footnotetext{
${ }^{4}$ See Basel Committee on Banking Supervision (2000).

${ }^{5}$ This issue has been empirically investigated by numerous studies, briefly reviewed in the next paragraph.

${ }^{6}$ With the term public bank I refer to a government owned or government guaranteed bank. This empirical result has important policy implications not only because of the implicit violation of the principle of "leveling the playing field" but also because of the recent dispute between the EU Commission and the German Landesbanks concerning illegal government aid. I refer to the German Landesbank not only because of this dispute but also because six of them rank among the top fifty European banks issuers of SND. See Sironi (2000).
} 
differentiate among the risks undertaken by banks. Such studies investigate the relationship between SND spreads and bank risk, the latter measured by both market and accounting variables. The existence of a statistically significant relationship was considered as a necessary, although not sufficient, condition for market discipline to be effective.

Early empirical work of this kind, based on U.S. bank holding company data from the early and mid 1980s, did not find any statistically significant relationship between SND spreads and bank risk $^{7}$. However, more recent studies based on data for longer and more recent time periods, while confirming the previous results for the mid-80s, found statistically significant relationships between SND spreads and various measures of bank risk ${ }^{8}$.

These diverging results have been explained by the significant change in U.S. regulatory treatment of bank SND investors over the period between the early eighties and the early nineties, with the apparent lack of market discipline of the early and mid eighties attributed to the presence of implicit government guarantees. Such guarantees were reinforced by the 1984 Continental Illinois bailout, during which no SND holder suffered any loss. The formalization of a too-big-to-fail (TBTF) policy by the Comptroller of the Currency several months later went even further in extending the safety net to uninsured bank creditors ${ }^{9}$. This policy changed significantly in the late eighties, when many bank debenture holders suffered losses, and was reversed with the 1991 Federal Deposit Insurance Corporation Improvement Act (FDICIA). Thus, conventional wisdom holds that investors in SND became more sensitive to the risk of the issuing U.S. banking organizations beginning in the late eighties. This risk sensitivity became stronger as regulators reduced the protection afforded to bank holding companies by the safety net ${ }^{10}$.

The second generation studies addressed the "sufficiency question" of whether the risk sensitivity of spreads is strong enough for market discipline to be effective. This issue has been investigated using rather differing approaches. Morgan and Tiroh (1999) compared the risk sensitivity of U.S. banks' bond spreads at issuance during the 1993-1998 period with that of U.S. non financial companies using traditional Moody's and Standard \& Poors issue ratings. They found that the spread/rating relationship is the same for the bank issues as for non-bank issues

\footnotetext{
${ }^{7}$ See Avery, Belton, and Goldberg (1988), and Gorton and Santomero (1990).

${ }^{8}$ See Flannery and Sorescu (1996), De Young et al. (1998), Jagtiani et al. (1999), and Covitz et al. (2000).

${ }^{9}$ See Carrington (1984).

${ }^{10}$ For a careful review of "first generation" studies, see Flannery (1998).
} 
and concluded that the bond market prices bank risk efficiently. Bliss and Flannery (2000) investigated whether the risk sensitivity of spreads is strong enough to affect bank management decisions such as reductions in leverage, dividend cuts, sale of new stock or changes in uninsured liabilities. They found that abnormal bond and stock returns are not typically followed by such actions and concluded that financial market signals are not strong enough to significantly affect managerial behavior. Covitz, Hancock and Kwast (2000) investigated whether a BHC decision to issue SND is affected by its risk profile. They found that riskier banks are indeed less likely to issue SND during times of banking sector stress or relatively volatile bond market conditions. They concluded that the introduction of a mandatory subordinated debt policy would significantly improve both indirect and direct market discipline.

This paper is in the spirit of the first generation studies, in that it investigates the risk sensitivity of SND spreads. However, it extends the existing literature in three important directions. First, it analyzes the European banking industry ${ }^{11}$. This is done through an empirical analysis of the risksensitivity of European banks' SND issuance spreads during 1991-2000. Testing for market discipline outside the U.S. is important not only as a check on robustness of previous results. Most of the recent work to improve banking regulation has been carried out with an international focus through the Basel Committee. On one hand, independent national regulations are considered increasingly incompatible with the global nature of the activities of major banks, to which most of the recent and currently undergoing efforts to reform the capital adequacy framework are addressed. On the other hand, any independent attempt by single national authorities to modify the existing capital adequacy framework would inevitably affect the relative competitiveness of large international banks, thereby violating the "level the playing field" principle. The same reasoning applies to the eventual introduction of a mandatory subordinated debt policy.

Second, the empirical analysis makes use of Moody's Banks Financial Strength (MBFS) and FitchIBCA Individual (FII) ratings as measures of bank risk. These ratings differ from traditional ones in that they focus on banks economic and financial conditions and do not take into account

\footnotetext{
${ }^{11}$ I am aware of one single empirical study based on European banks SND data. Bruni and Paternò (1995) analyzed the issue of market discipline by examining the statistical relationship between secondary market spreads, Moody's ratings and accounting variables as proxies of bank risk and concluded in favor of the risk sensitivity of SND spreads. However, their analysis was limited to a sample of 28 SND issues for which one single day secondary market spreads were collected, and two accounting variables (leverage and return on assets). This is partly because their study was dedicated to a wider set of issues than the one related to the risk sensitivity of SND spreads.
} 
any external support from banks owners, state authorities or other official institutions. As such, they represent ideal candidates for the cross-country comparison of banks risk profiles. Indeed, many of the accounting variables that have been shown by U.S. empirical studies to be statistically significant in explaining spread differences are either unavailable or are measured differently across European countries ${ }^{12}$.

Third, an analysis of the average interest rate government subsidy received by European public banks is performed. Testing for the existence of statistically significant differences in the risk sensitivity of SND spreads between private and public banks is of particular interest because of the attention that the subject of government aid is currently receiving in Europe. Indeed, the twelve state-backed German Landesbank are currently in a dispute with the European Commission because of illegal government aid received in the form of capital from local governments at below market rates ${ }^{13}$. While this kind of direct support is easy to identify and quantify, indirect aid in the form of government guarantees has received less attention. ${ }^{14}$

\section{RESEARCH METHODOLOGY}

Banks' SND issuance spreads over the corresponding maturity Treasury bonds reflect investors' perception of the credit risk of the issuer. As such, they are a function of six main factors: (1) the economic and financial condition of the issuing bank, (2) the time to maturity of the issue, as this affects its default risk premium (Merton, 1974), (3) the issue amount, as this in turn is believed to affect secondary market liquidity, (4) any explicit or implicit government guarantees ${ }^{15}$ perceived by market investors, (5) the currency of denomination ${ }^{16}$, and (6) the time of the issue, as bond market conditions change over time. Following this reasoning, the empirical analysis involves cross-sectional regressions ${ }^{17}$ of the form:

\footnotetext{
${ }^{12}$ This is particularly true for accounting variables used to proxy for credit risk, such as non-performing loans and loan loss reserves.

${ }^{13}$ See The Economist (2000).

${ }^{14}$ German Lander (states) hold direct stakes in many of the Landesbanks and provide them with an unlimited state guarantee. This gives the Landesbanks a top-notch credit rating, allowing them to raise funds at cheaper rates than private-sector competitors.

${ }^{15}$ An explicit guarantee may be present for public banks.

${ }^{16}$ The latter is a relevant factor because of the different credit standing and liquidity of national Treasury securities. The spread of an SND issue is computed as the difference between the SND yield to maturity and the equivalent Treasury yield. Therefore, a U.S. dollar denominated SND issue could, other things being equal, have a higher spread than an Italian lira denominated issue simply because the Italian Treasury security has a lower credit quality and liquidity than the U.S. Treasury security.

${ }^{17}$ Despite the cross-sectional nature of the empirical analysis, some temporal variation is present as many banks issued SND more than once over the sample period.
} 


$$
\operatorname{SPREAD}_{i}=f\left(\operatorname{RISK}_{i}, \text { MATU }_{i}, \text { AMOUNT }_{i}, \operatorname{COUNTRY}_{i}, \operatorname{CURR}_{i}, Y_{E A R_{i}}\right)+\varepsilon_{i}
$$

where

$\mathrm{SPREAD}_{\mathrm{i}}=$ the difference between the yield to maturity at launch of issue $\mathrm{i}$ and the yield to maturity of the corresponding currency Treasury security ${ }^{18}$ (corresponding means a security with similar maturity issued by the Treasury of the government with the currency in which the SND issue is denominated);

RISK $_{\mathrm{i}} \quad=$ alternative measures of the default risk of the issuing bank;

MATU $_{\mathrm{i}}=$ the time to maturity (in years) of issue $\mathrm{i}$;

AMOUNT $_{\mathrm{i}}=$ the $\log$ of the U.S. dollar equivalent amount of issue $\mathrm{i}$;

COUNTRY $_{\mathrm{i}}=$ the country where the issuing bank is registered;

CURR $_{\mathrm{i}} \quad=$ the currency of denomination of issue $\mathrm{i}$;

YEAR $_{\mathrm{i}} \quad=$ the year of issuance.

Note that, in contrast to most of the studies on market discipline conducted using U.S. banks' SND data, this study is based on primary market spreads. We avoid use of secondary market spreads because of the poor liquidity of the secondary market for European banks' SND issues ${ }^{19}$. Yields on new issues reflect actual transaction prices rather than brokers' "indicative prices", estimates derived from pricing matrices or dealers' quotes ${ }^{20}$. As such, they provide a more accurate measure of the actual cost of subordinated debt for banks and of the risk premium demanded by investors. Using primary market spreads also permits use of "fresher" ratings because ratings of new issues reflect the raters' assessment near the time of issuance of the bonds repayment prospects $^{21}$.

The main disadvantage of using spreads at issuance is that they are influenced by market conditions of the time of issue and are therefore not directly comparable. We address this problem by using control variables for the time of issue.

\footnotetext{
${ }^{18}$ Interpolated yield curves are used when no Treasury security of similar maturity is available. Spreads for Euro denominated issues are computed using either the French OAT or the German Bund yield curve, depending on the closest available maturity.

${ }^{19}$ See Sironi (2000).

${ }^{20}$ Secondary market prices can even be misleading if dealers quote strategically.

${ }^{21}$ The Federal Reserve Study Group on Subordinated Notes and Debentures reports that "market participants generally believed that changes in rating agencies opinions tended to lag information revealed in secondary market prices.” Board of Governors of the Federal Reserve System (1999).
} 
We employ four alternative specifications of equation (1), each using different risk proxies. The first one is based on Moody's and Standard \& Poors issue ratings ${ }^{22}$. These are ratings assigned by one or both rating agencies to the single issue at the time of issuance. As such, they reflect both the issuing bank default risk and the facility seniority and security structure ${ }^{23}$.

A second specification based on Moody's and Standard \& Poors issuer ratings has been tested in order to focus on the role of the issuing banks' default risk. These are the prevailing senior debt ratings, at the time of the issue, assigned by one or both the rating agencies to the issuing bank. While these ratings are good proxies for the issuing bank "creditworthiness" or "ability to meet its financial obligations" 24 , they do not necessarily represent good proxies for a bank's risk profile or, more generally, for its economic and financial conditions. Indeed, the creditworthiness or future ability to make timely payments of an obligor could be excellent even if its economic and financial conditions are poor when an explicit or implicit government guarantee is in place. This is particularly true for continental Europe, where many banks are still government (either national or local) owned and troubled banks' uninsured creditors have often been bailed out by national authorities.

Because of this problem, the rating agencies themselves have introduced new bank ratings that focus on the economic and financial soundness of the bank, without taking into consideration any external support from State authorities or its owners. Two main types of ratings are currently available: Moody's Bank Financial Strength (MBFS) and Fitch IBCA Individual (FII). Rating definitions and scales are presented in Appendix 1, 2 and 3 respectively ${ }^{25}$. FII ratings were introduced in the late eighties and are therefore available for most of the SND issues used in the empirical analysis. On the other hand, MBFS ratings were introduced more recently and are therefore available for a smaller subset of sample issues. Appendix 4 provides information on

\footnotetext{
${ }^{22}$ Empirical results are based on the average numerical value of the ratings assigned by S\&P and Moody's. When this average value was not an integer number, rounding to the higher (less risky) integer value has been applied. An alternative based on lower (more risky) integer value rounding has been tested and found to produce similar results. Rating scales and availability are presented in Appendices 3 and 4 respectively.

${ }^{23}$ This in turn affects the expected loss given default (LGD).

${ }^{24}$ In the words of S\&P, "A credit rating is S\&P's opinion of the general creditworthiness of an obligor, or the creditworthiness of an obligor with respect to a particular debt security or other financial obligation, based on relevant risk factors." S\&P Corporate Ratings Criteria, 1998, p.3. A rating in Moody's words is “... an opinion on the future ability and legal obligation of an issuer to make timely payments of principal and interest on a specific fixed income security." Moody's Credit Ratings and Research (1998), p. 4.

${ }^{25}$ The two ratings are both based on a 9 notches scale and on very similar definitions. The two systems also tend to rate banks in a similar way. Indeed, differences higher than 1 notch only occur in $6.67 \%$ of the 165 cases when both ratings were available for the empirical sample. See Appendix 4.
} 
ratings availability and concordance ${ }^{26}$. MBFS and FII ratings are used in the third specification of equation (1).

In all three ratings-based specifications, ratings are represented by dummy variables ${ }^{27}$. Each dummy variable is equal to 1 if the issue or issuer has the corresponding grade and zero otherwise. Dummy variables allow more flexibility than would result from imposing a linear specification.

Finally, a fourth specification based on accounting measures of bank risk has been employed (Table 7). Selected balance-sheet variables that previous authors have found to be important in predicting the likelihood of bank failure are used as predictors of spreads. The model employed in this final specification closely resembles those used in earlier studies and is based on the following simplified representation of bank risk $^{28}$ :

$$
\text { BANKRISK }=f(\text { LEVERAGE, ASSETQUALITY }, \text { PROFITABILITY })
$$

The following bank-specific variables are employed: ${ }^{29}$

LEV the ratio of total (book) liabilities to the book value of equity. Higher leverage indicates higher default risk.

ROA the ratio of annual net income to the average of the preceding and current year-end total assets. Higher profitability generally signals greater efficiency. As profitability tends to be serially correlated, a higher value of this variable should indicate lower default risk. However, a higher value might also indicate compensation for higher risk-taking and therefore be positively correlated with SPREAD ${ }^{30}$.

NLTA the ratio of net loans to total assets. This variable should positively affect spreads if loans are riskier than other assets or if their risk is simply more difficult to assess ${ }^{31}$.

LLRGL the ratio of loan loss reserves to total loans. This variable should positively affect SPREAD as higher reserves indicate, ceteris paribus, higher expected losses.

\footnotetext{
${ }^{26}$ Concordance is here considered as the simple equivalence of the numeric value of the two ratings. The term "agreement" used by other studies is not considered appropriate as rating agencies do not necessarily map their ratings to each other.

${ }^{27}$ One of the possible dummies must be dropped to avoid collinearity in the data. The dropped one is here the top quality one so that each dummy $\mathrm{j}$ coefficient can be interpreted as the average spread between rating $\mathrm{j}$ issues and the top notch rating (AAA in S\&P, Aaa in Moody's, A for both MBFS and FII) issues.

${ }^{28}$ Without any compelling theory suggesting otherwise, a linear specification has been used for this accounting based specification of equation (1).

${ }^{29}$ For each SND issue, the variables refer to the year preceding the date of the issue.

${ }^{30}$ See Flannery and Sorescu (1996), p. 1358.

${ }^{31}$ This ratio has been used by Flannery and Sorescu (1996) and not found to be statistically significant.
} 
However, a higher value of LLRGL might also be perceived by SND investors as a larger cushion against unexpected losses. A negative relationship between SPREAD and LLRGL would result in this case.

NPLGL the ratio of non-performing loans to total loans. A higher value implies greater default risk, ceteris paribus.

Following previous studies, a set of interactive variables is also included in order to capture nonlinear risk relationships.

ROALEV the product of ROAA and LEV. This variable should negatively affect SPREAD as profitability becomes more important for more leveraged banks.

LLRLEV the product of LLRGL and LEV. This variable should positively affect SPREAD as higher credit risk becomes more relevant for more leveraged banks.

NPLLEV the product of NPLGL and LEV. This variable should capture the joint effect of leverage and credit risk and positively affect SPREAD.

Control variables used in the four alternative specifications include:

MATU the time to maturity (in years) of the issue.

AMOUNT the log of the U.S. dollar-equivalent amount of the issue.

D91, D92, ..., D00 - Year dummies. These should mainly capture the intertemporal variations in bond market conditions ${ }^{32}$.

DEURO, DSTG, DFFR, DDEM, DDFL, DUSD, DOTHERCUR - Currency dummies. These should capture both the different credit standing and liquidity of the different national Treasury securities and SND investors' currency preferences ${ }^{33}$.

DGER, DFRA, DUK, DNET, DSPA, DSWI, DOTHERCOU - Country dummies. These should capture both differences in macroeconomic conditions and cross-country differences in safety nets or implicit government guarantees ${ }^{34}$.

PUBLIC a dummy variable that equals 1 if the issuing bank is a public one and zero if it is a private bank. A public bank is here defined as either a government (national or local) owned bank or a bank that benefits from explicit government guarantees.

\footnotetext{
32 The D91 dummy variable has been dropped to avoid collinearity in the data.

${ }^{33}$ The OTHERCUR dummy variable has been dropped to avoid collinearity in the data.

34 The OTHERCOU dummy variable has been dropped to avoid collinearity in the data.
} 
$\mathrm{TA}^{35}$ a control variable for the size of the issuing bank. It is computed as the ratio of the issuing bank's total assets to the total assets of the largest bank in the sample in the year of the observation ${ }^{36}$. This variable should negatively affect default risk as larger banks tend to have more diversified portfolios, be better managed and eventually benefit from TBTF policies.

\section{DAta SourCeS AND SAMPLE Characteristics}

The data are from five main sources: (1) Capital Data BondWare, (2) Moody's Corporate Default, (3) FitchIBCA BankScope, (4) Moody's Mergent Bond Record, and (5) WorldScope. Capital Data reports information on the major debt and equity issues worldwide. As far as bonds are concerned, Capital Data Bondware provides information on both issuers (nationality, Moody's and S\&P current ratings, industry, etc.) and issues (currency, announcement and closing dates, maturity date, years to maturity, spread at issuance, issue type, face value, coupon, etc.). Spreads at issuance for all European bank issues of fixed rate, non-convertible, nonperpetual and non-callable SND during the 1991-2000:Q1 were collected. The resulting sample has 407 fixed rate subordinated bonds, of which 92 are perpetual. Of the remaining 315, 5 are callable issues and 20 are either convertibles or hybrid issues, leaving a total of 290 fixed rate, non-callable, non-convertible, straight maturity subordinated coupon notes and debentures.

Moody's and Standard \& Poors (S\&P) ratings at issuance for these 290 issues are from Capital Data BondWare (154 issues) or from the Moody's January, 2000 release of Moody's Corporate Default Database (136 issues). The latter is a complete history of Moody's long-term rating assignments for both U.S. and non-U.S. corporations and sovereigns. Both ratings on individual bonds and issuer ratings are included, as are some bond and obligor characteristics such as borrower names, locations, CUSIP identifiers, ultimate parent companies, bond issuance dates, original maturity dates, seniority, and coupon.

\footnotetext{
${ }^{35}$ This control variable has not been included in the specification based on Moody's' and S\&P issue and issuer ratings. This is because these ratings should capture both economic type advantages of size and TBTF type conjectural guarantees. On the other side, a control variable for size has been included in the specification based on MBFS and FII ratings because these do not capture any TBTF type effect.

${ }^{36}$ As SND issues are made in different years, using the log of total assets would have led to higher values for more recent issues. Adjusting for inflation would not eliminate this bias because of the real growth of banks' total assets. An alternative specification based on the ratio between the issuing bank total assets and the corresponding year sample banks average total assets has also been tested and found to produce nearly identical results. The one employed here has been chosen because the resulting value is confined between zero and one.
} 
Because Capital Data Bondware only provides information on issuers' current Moody's and S\&P ratings, issuer ratings at the time of sample bonds' issuance have been collected from either the Moody's Corporate Default database or FitchIBCA BankScope. The latter is a database with information on financial statements, ratings, shareholders and subsidiaries of over 10,000 banks worldwide. This database is also the source of our balance sheet data and accounting ratios. MBFS and FII ratings are collected from two sources: FitchIBCA Bank Scope and Moody's Mergent Bond Record. The latter is a monthly publication of all Moody's updated corporate, convertibles, governments and municipals ratings ${ }^{37}$.

European banks issue SND either directly or through wholly owned subsidiaries located in tax havens such as Luxembourg, the Cayman Islands, the Bahamas and Jersey. Indeed, of the 290 SND in the sample, 52 were issued through such subsidiaries. Information on the parent company for these issues is from both Moody's Corporate Default and the FitchIBCA Bankscope database. Finally, WorldScope provides information on both balance sheet and stock market data for major banks worldwide. This database is the source of stock market capitalization data for market leverage computation purposes. Detailed information on sample characteristics is provided in Tables 1,2 and 3. The issuing banks for the sample issues are listed in Table 4.

\section{EMPIRICAL RESULTS}

\subsection{The Impact of Traditional Moody's and S\&P Ratings on SND Spreads}

Columns 2 and 3 of Table 5 report estimates when conventional issue and issuer ratings are used as proxies for RISK in (1). F statistics for tests whether rating coefficients are jointly different from zero as well as adjusted $\mathrm{R}^{2}$ are reported at the bottom of the table. All rating dummies are statistically significant at the $1 \%$ level with the exception of Rating $=2$ in the issuer specification (Aaa/AAA is the omitted rating category). The monotonic pattern of dummy coefficients indicates that spreads rise when ratings worsen. Adjusted $\mathrm{R}^{2}$ of 0.688 and 0.692 respectively indicate that ratings and control variables explain a significant portion of SND spreads' cross sectional variability. Results are quite similar for issue and issuer ratings, perhaps because issue

\footnotetext{
${ }^{37}$ MBFS ratings are not present in the Moody's Corporate Default database. They were collected from the Mergent Bond Record publication of the month preceding the correspondent SND issue.
} 
and issuer ratings are highly correlated, with issuer ratings being on average 0.9 notch higher (4.2 versus 3.3) than issue ratings ${ }^{38}$ (see Table 2, Panel A and B).

MATU has a positive coefficient as expected and is statistically significant at the $1 \%$ level. Quite surprisingly, AMOUNT has a positive and statistically significant coefficient in both alternative specifications. One possible explanation for this result is based on the different investors to which SND issues are usually targeted. European banks raise subordinated debt capital in two main ways ${ }^{39}$ : (1) through their own distribution networks with private placements mainly targeted at private retail clients, and (2) through public issues mainly targeted to institutional investors. The retail issues have a smaller average size than the wholesale issues and are targeted to investors with less bargaining power. Therefore, European banks may be able to pay lower spreads on retail issues than on institutional issues. An alternative explanation is based on the concept of "scarcity value". Smaller issues are usually issued by smaller banks which in turn raise funds in the capital markets less frequently than larger banks. Investors might therefore associate a higher portfolio diversification value to smaller size SND issues ${ }^{40}$ and price them accordingly.

STG (British pound) and USD (U.S. dollar) are the only statistically significant currency dummy variables. Both have positive coefficients, indicating that pound sterling and U.S. dollar denominated SND issues have higher spreads than other currencies denominated ones. This result flows from the relatively higher than average credit standing and liquidity of the Treasury issues of those countries. Because their Treasury issues pay lower yields, and spreads are computed by subtracting such yields from SND yields, SND spreads tend to be higher for dollar and sterling denominated issues.

No country dummy variable is statistically significant with the exception of the UK in the issuer ratings specification. That positive coefficient implies that British banks pay above European average spreads on their SND issues. While a clear interpretation of this empirical result is difficult to provide ${ }^{41}$, one possible explanation is a difference between the state of the British

\footnotetext{
${ }^{38}$ Rating agencies tend to rate subordinated issues one notch below the corresponding issuer senior debt rating if the latter is investment grade and two notches below if it is speculative grade. All banks in the sample are rated investment grade by both Moody's and Standard \& Poors.

${ }^{39}$ See Sironi (2000).

${ }^{40}$ See Levich (1998), pp. 454-455, for a description of scarcity value in bond markets.

${ }^{41}$ The effect of the UK not being a member country of the Monetary Union should already be captured by the statistically significant positive coefficient of the dummy variable for pound sterling and would only refer to a small fraction of the sample SND issues.
} 
economic cycle and that of the major continental European countries. Rating agencies tend to evaluate firms "through the cycle" as opposed to "point in time" ratings that do not incorporate the current state and perceived prospects of the economic cycle. However, financial markets are forward looking and tend to price bonds according to the expected financial and economic conditions of the issuers. Thus, worse economic conditions in the UK than in other European countries could explain why a country dummy has incremental explanatory power relative to the ratings dummies ${ }^{43}$.

Finally, year dummies (not reported) are all statistically significant at the $1 \%$ level.

\subsection{Do SND Investors Really Price European Banks' Risk Profile?}

While the relationship between spreads and traditional Moody's and Standard \& Poors ratings provides strong evidence that SND investors are sensitive to default risk, it does not necessarily imply that they are sensitive to the issuing banks' risk profiles. Market discipline requires investors to price the issuing banks intrinsic risk profile. This might differ from banks' default risk or the risk of loss by investors if any explicit or implicit government guarantee is in place ${ }^{44}$. The third specification of (1) uses the Moody's and FitchIBCA ratings of standalone creditworthiness to test for investors sensitivity to intrinsic risk. Results are much weaker than the previous ones (Table 5, column 3). Only one rating dummy is statistically significant and the coefficients do not rise monotonically as rating worsens. The adjusted $\mathrm{R}^{2}(0.569)$ is significantly lower than for previous specifications $(0.692 \text { and } 0.688)^{45}$. In addition, the GER country dummy variable becomes statistically significant at the $1 \%$ level with a negative coefficient. These results seem to indicate that SND investors do not price the true risk profile of the issuing banks and that German banks benefit from lower spreads relative to their European competitors.

However, a significant fraction of the German banks are public ones (see Table 3). Table 6 reports results of a modified version of the MBFS-FII ratings based specification that includes a

\footnotetext{
${ }^{42}$ See Carey and Treacy (1999).

${ }^{43}$ As will be shown later, the statistically significant positive coefficient for British banks disappears in the second part of the decade, when the UK macroeconomic conditions became significantly better than the ones prevailing in continental Europe.

${ }^{44}$ An intuitive proxy for this difference between banks intrinsic risk profile and default risk is represented by (the complement to one of) the correlation between traditional Moody's and Standard \& Poors issuer ratings and MBFS and FII ones. Appendix 5 shows that while the average sample correlation between Moody's and Standard \& Poors issuer and issue ratings is extremely high (0.918), the correlation coefficient between traditional issuer ratings and MBFS-FII ones is much lower (0.437). This result is mostly driven by the low correlation coefficient for German banks $(0.121)$ and other countries ones $(0.198)$.

${ }^{45}$ Consider that control variables alone produce an adjusted $\mathrm{R}$ square of 0.554 .
} 
dummy variable for public banks (Table 6, column 2) and one based on a sub-sample of private banks only (Table 6, column 3). In addition, the control variable TA is included in order to capture the possible TBTF type implicit guarantees ${ }^{46}$.

Three interesting results emerge. First, all MBFS-FII rating dummies except for rating $=2$ are statistically significant at the $1 \%$ level in both specifications. Their signs and relative values are again as expected (the only exception is rating $=6$, the coefficient of which is lower than expected). The adjusted $\mathrm{R}^{2}$ for the two alternative specifications are significantly higher than for the basic specification (shown in column 1 for comparison), where no control for public banks is present (0.672 and 0.674 compared to 0.590). These results support the hypothesis that SND investors are sensitive to private banks' financial soundness as reflected by MBFS-FII ratings.

Second, the public bank dummy variable is strongly statistically significant with a relatively high negative coefficient (-40.31). This suggests that European public banks pay approximately 40 basis points less on SND than their risk profile would imply. Given that subordinated debt can be included in BIS regulatory capital, this implicit subsidy represents a clear violation of the "level the playing field" principle originally set forth by the Basel Committee for Banking Supervision $^{47}$.

The TA control variable is not statistically significant, suggesting that SND investors do not consider larger banks to benefit from TBTF type conjectural guarantees.

\subsection{Do Accounting Variables Add Value to Financial Strength Ratings?}

When comparing banks from different countries, two problems arise from different accounting and disclosure rules. First, the definition of certain variables may differ across European countries. For example, the accounting for non-performing loans and loan loss reserves, two variables that have been shown by past studies to be statistically significant in explaining spread differences, is not uniform across countries. Second, many of the balance-sheet variables used to proxy for bank risk are not available for all the SND issuing banks in the sample. This problem is particularly severe for credit risk proxies such as LLRGL and NPLGL. Because of this second

\footnotetext{
${ }^{46}$ Indeed, the advantages that size provides in terms of diversification or access to markets with monopolistic rents such as corporate finance, asset management and trading, should already been incorporated in the MBFS and FII ratings.

${ }^{47}$ Note that the GER country dummy variable is not statistically significant once a dummy variable for public banks is included or a sub-sample of private banks only is analyzed.
} 
problem, three sub-samples - A, B and C - of different size (285, 189 and 94 observations respectively) are used in the regression analysis reported in Table 7.

Four alternative specifications are presented for each sample in order to evaluate the relative explanatory value added of accounting variables with respect to control variables and MBFS-FII ratings: (1) control variables only, (2) control variables and MBFS-FII rating dummies, (3) control and accounting variables, and (4) all variables. To save space, results are reported only for the TA and PUBLIC control variables because of their usefulness in interpreting the empirical evidence ${ }^{48}$.

Three important results emerge. First, accounting proxies of bank risk never add significant value in explaining European banks' SND spreads. Indeed, adding balance-sheet ratios to control variables increases the adjusted $\mathrm{R}^{2}$ only marginally for all three sub-samples. The same result occurs when accounting ratios are added to the second specification, which already includes control variables and MBFS-FII rating dummies ${ }^{49}$. The opposite is true for MBFS-FII ratings. Adding rating dummies to the first specification based on control variables only or to the third one based on control and accounting variables significantly improves the adjusted $\mathrm{R}^{2}$ for all three sub-samples.

Although the rating agencies publish descriptions of their methods, the factors that determine MBFS and FII ratings are difficult to understand perfectly. However, there are at least four main intuitive advantages of agencies' estimates of bank risk when compared to estimates based on accounting measures alone. First, ratings may be based on more extensive analysis of risk than is feasible in statistical models that rely on accounting data only. Second, even if a general agreement on the variables that affect the risk profile of a bank exists, no compelling theory about the functional form of this relationship is available. Third, additional qualitative factors such as management expertise are generally considered by rating agencies' analysts. Fourth, while accounting variables are backward looking measures of bank risk, analysts' evaluations are mostly forward looking in that they focus on the banks' future ability to meet their financial obligations ${ }^{50}$.

\footnotetext{
${ }^{48}$ Other control variables include MATU, AMOUNT, year, currency and country dummies.

${ }^{49}$ MBFS-FII ratings dummies are almost always statistically significant with the expected sign and relative values.

${ }^{50}$ One might also add that rating agencies put their reputation at risk. As stated by Cantor and Packer (1994), "Over the years, the discipline provided by reputational considerations appears to have been effective, with no major scandals in the ratings industry of which we are aware".
} 
Looking in more detail at individual accounting variables, while signs of coefficients are often as expected, they are seldom statistically significant. LEV always has a positive coefficient but is statistically significant only for sub-sample C. Quite surprisingly, ROA has a positive coefficient in most specifications, although statistically significant only for sample $\mathrm{C}$ (at the 5\% level). However, a strongly statistically significant (at the 1\% level) negative coefficient for the interactive variable ROALEV also appears in sample $\mathrm{C}$, suggesting that an increase in ROA reduces spreads only for less-capitalized institutions. Results for NLTA are mixed. The coefficient is positive as expected and statistically significant (at the 5\% level) for the fourth specification of sub-sample A. However, the coefficient is negative and weakly statistically significant (at the 10\% level) for the third specification of sub-sample $\mathrm{C}$, and the coefficient values are generally very low, suggesting that SND investors do not consider this variable to be a key predictor of bank default risk ${ }^{51}$. LLRGL has a positive and statistically significant coefficient as expected, indicating that higher loan loss reserves are considered by SND investors to be a signal of poor asset quality. However, LLRLEV has a negative and statistically significant coefficient, suggesting that a higher LLRGL ratio is perceived as a larger cushion against unexpected losses for less-capitalized banks. Finally, neither NPLGL nor NPLLEV are statistically significant.

The second interesting empirical result concerns the TA control variable. This is always statistically significant at the $1 \%$ level with the expected negative sign in the specifications that do not include MBFS-FII rating dummies. This result suggests two important conclusions: (1) size is one of the key factors that both SND investors and rating agencies take into consideration in evaluating a bank's financial soundness, and (2) no TBTF type implicit guarantees are perceived by SND investors ${ }^{52}$.

Finally, the PUBLIC dummy variable is always statistically significant at the $1 \%$ level with a negative coefficient for both sub-sample A and B specifications. This is not the case for subsample $\mathrm{C}$, where only two public banks remain in the sample.

\footnotetext{
${ }^{51}$ Indeed, the 0.385 coefficient resulting from the fourth specification of sub-sample A indicates that an increase of 10 percentage points in the NLTA ratio only increases SPREAD by 3.85 basis points.

${ }^{52}$ If investors did perceive TBTF guarantees to exist, TA would probably be significant in the MBFS-FII rating based specifications as these ratings explicitly avoid taking into consideration any kind of external support. Large banks can be perceived as less risky by private investors for two main reasons: (1) economic advantages, such as higher portfolio diversification, economies of scale or access to activities with monopolistic rents, and (2) regulatory advantages, namely TBTF guarantees. As MBFS and FII ratings capture economic advantages only, any residual size effect should be attributed to TBTF conjectural guarantees.
} 


\subsection{Did Market Discipline of European Banks Strengthen Over Time?}

The same kind of cross-sectional regressions based on MBFS and FII ratings are estimated for sub-samples in order to check whether any significant change in the risk sensitivity of SND spreads occurred during the nineties. Two sub-samples of approximately the same size are used: 1991-1996 (146 observations) and 1997-2000:Q1 (144 observations). Results are reported in column 1 and 2 of Table $8^{53}$.

The adjusted $\mathrm{R}^{2}$ are similar for the two sub-samples. However, four major differences emerge. First, no rating dummy variable is statistically significant in the 1991-96 sub-sample, suggesting that SND investors were not sensitive to the issuing banks' risk profiles during the first half of the decade. The opposite occurs for the 1997-2000:Q1 sub-sample, where most rating dummies are strongly statistically significant with the expected signs and relative values. Similarly, the Ftests are statistically significant for the 1997-2000:Q1 sub-sample only.

Second, TA has a negative and statistically significant (at the 5\% level) coefficient in the 199196 sub-sample but is insignificant for the later period. This suggests that TBTF type guarantees, perceived by SND investors to be in place in the first half of the decade, gradually vanished in the second half.

Third, the UK dummy has a positive and statistically significant (at the 5\% level) coefficient for the 1991-96 sub-sample, but not for the later period. This suggests an alternative explanation to the aforementioned difference in economic cycles. If UK banks never had TBTF guarantees, and continental European countries gradually diminished such guarantees, then UK banks gradually lost their relative interest rate disadvantage.

Finally, the PUBLIC dummy variable is strongly statistically significant in both sub-samples and has a negative coefficient that is larger for the later sample, suggesting that the implicit interest rate government subsidy has increased from the first to the second half of the decade. This result is consistent with the evidence of an increasing risk-sensitivity of SND investors (with reduced implicit guarantees of private banks).

\subsection{Robustness checks}

Variations of the specifications reported in Table 6,7 and 8 were estimated in order to assess the robustness of the conclusions concerning the risk sensitivity of SND spreads, its evolution over time and the relative explanatory power of MBFS-FII ratings versus accounting ratios. 
Separate regressions using MBFS ratings only (219 observations) and FII ratings only (236 observations) were estimated as a check on the use of average ratings. Using the average numerical value of ratings coming from two different sources could produce misleading results if the two agencies adopt significantly different criteria in evaluating banks' economic and financial conditions. Results are reported in column 1 and 2 of Table 9. No significant difference emerges between the two: most rating dummies are statistically significant with the expected sign for both sub-samples. TA and UK control dummies are not statistically significant in the MBFS sub-sample, while AMOUNT is not statistically significant in the FII sub-sample. These differences are most likely the consequence of the MBFS sub-sample being concentrated in the second half of the decade (these ratings were originally introduced by Moody's in 1995). Columns 3 and 4 of Table 9 report results based on the 165 SND issues for which both FII and MBFS ratings are available and show that all differences disappear once the analysis is focused on the same time period.

Two checks of robustness regarding the poor explanatory power of the balance sheet variables are conducted. First, alternatives to the measures of bank leverage and profitability that appear in the accounting based specifications of Table 7 are used. LEV is replaced with three different variables: (1) MKTLEV, the ratio between total (book) liabilities and market capitalization, (2) BISTOT, the BIS total capital ratio and (3) TIER1, the BIS tier 1 capital ratio ${ }^{54}$. The latter two variables can differ significantly from the reciprocal of LEV if the ratio between risk-weighted assets and total assets is different across banks and/or across time. Results (not reported) are similar to those obtained with LEV in all three cases. The adjusted $\mathrm{R}^{2}$ of the different regressions do not improve in any material way relative to $\mathrm{R}^{2}$ obtained with the control variables and rating dummies only. MKTLEV has a positive coefficient in sub-sample B only and is never statistically significant. BISTOT and TIER1 both always have negative coefficients as expected but are never statistically significant. ${ }^{55}$

Alternative measures of bank profitability are also used. ROA is replaced with two different variables: ROE, the ratio of net income to average equity, and PTOITA, the ratio of Pre-Tax Operating Income to Total Assets. The latter could add explanatory power if SND investors

\footnotetext{
${ }^{53}$ To save space, results are reported only for certain control variables (AMOUNT, MATU, PUBLIC, TA and UK).

${ }^{54}$ These variables were available for 215,270 and 261 observations respectively.

${ }^{55}$ While one would expected BISTOT to perform poorly (SND investors do not receive any protection from Tier 2 capital), the result for TIER1 is quite surprising.
} 
concentrate on operating profit as a better proxy of long-run sustainable profitability. Results are similar for the two alternative measures of bank profitability. PTOITA has a negative coefficient in all three sub-samples (A, B and C) but never statistically significant. ROE has a negative and statistically significant (either at the $5 \%$ or at the $1 \%$ level) coefficient in all three sub-samples but its use has little effect on the adjusted $\mathrm{R}^{2}$. This is probably because part of its explanatory power is already included in LEV.

Three robustness checks focus on the temporal evolution of European banks SND spreads risksensitivity. First, regressions for the usual 1991-96 and 1997-2000 sub-samples are estimated using traditional Moody's and Standard \& Poors issue ratings rather than the FII-MBFS ones. As the traditional ratings incorporate both economic and financial conditions of the issuing banks and implicit guarantees, one would expect the empirical results for the two sub-samples not to show any significant difference. Indeed, most rating dummies are statistically significant with expected signs and with similar patterns of coefficient values in both sub-samples (columns 3 and 4 of Table 8). F tests are also strongly statistically significant in both sub-samples ${ }^{56}$.

Second, estimation samples were restricted to those SND issues made by banks that issued in both sub-periods. This was aimed at testing whether the improvement in the risk-sensitivity was simply due to a change over time in the identity of issuing banks. Results, reported in columns 5 and 6 of Table 8, reject this hypothesis and confirm the basic findings: only one rating dummy variable is statistically significant (at the 10\% level) in the 1991-96 sub-sample and the relative values of coefficients are not as expected. In contrast, most of the rating dummies are statistically significant, with the expected signs and relative values, in the 1997-2000:Q1 sample. The statistical significance of the $\mathrm{F}$ test used to determine if rating coefficients are jointly different from zero (Fb) also improves in the 1997-2000:Q1 sub-sample.

Third, the entire 1991-2000:Q1 sample was split into three (rather than two) time periods (199195, 1996-97 and 1998-2000:Q1) of approximately the same size (100, 92 and 98 observations respectively). Results, reported in columns 7,8 and 9 of Table 8, confirm the basic findings described previously. Rating dummies are not statistically significant and do not have expected sign and relative value coefficients in the 1991-95 sub-sample. Most of them become statistically significant with expected sign and relative value coefficients in both the 1996-97 and 1998-

\footnotetext{
${ }^{56}$ The UK dummy variable is again statistically significant in the 1991-96 sub-sample only, suggesting that the economic-cycle related explanation is the most likely one.
} 
2000:Q1 sub-samples, and F-test results are consistent with such a change. Results similar to those for the two-period split are also obtained for the UK dummy (statistically significant in the 1991-95 and 1996-97 sub-samples only) and PUBLIC (increasing negative coefficient).

Finally, cross-sectional regressions based on accounting measures of bank risk were estimated for sub-samples of single country issues ${ }^{57}$. This was done to test whether the poor performance of balance sheet measures of bank risk might be attributed to cross-country differences in accounting rules and standards. While single accounting ratios were still found not statistically significant, their coefficient signs were generally as expected. However, their joint explanatory power, measured in terms of the adjusted $\mathrm{R}^{2}$ square increases over the ones obtained with control variables only, was still relatively poor and significantly below the power of MBFS-FII rating dummies.

\section{Conclusions}

Three major conclusions stand out from the empirical work presented in this paper. First, SND investors appear to rationally discriminate between the different risk profiles of European banks. Second, the risk sensitivity of SND spreads has been increasing over time, suggesting that implicit guarantees such as TPTF policies were present in the first half of the nineties and became weaker or vanished during the second part of the decade. Third, European public banks benefit from a significant government subsidy in the form of a lower cost of SND issues, the value of which has been increasing over time. These conclusions have important policy implications for both the current capital adequacy framework and any future mandatory subordinated debt policy. As far as the latter is concerned, requiring banks to issue a minimum amount of SND would, in light of the first two conclusions, likely enhance market discipline of banks and supplement prudential regulatory discipline. It is also reasonable to believe that this study underestimated the extent of market discipline that would be associated to such a policy because it ignored European banks that did not issue SND. For some such banks, their risk profile would have made SND very expensive.

However, further research is needed before a clear conclusion on the net benefit of a mandatory subordinated debt policy can be reached. Three conditions are necessary for market discipline to be effective: (1) complete and timely information on banks risk profiles must be available, (2) no 
bailout must be anticipated and banks' creditors must consider themselves at risk in the event of default, (3) banks must react to market signals. Condition 1 can be undermined by a lack of disclosure and, more generally, by the increasing complexity of banks' risks coming from both the banking and the trading book. Condition 2 can be violated by too-big-to-fail (TBTF) policies or other forms of implicit government guarantees that exist if the safety net is extended beyond its de-jure boundaries to protect uninsured bank creditors. Finally, condition 3 can be violated either if private investors' risk aversion is not strong enough or if the borrowing bank has no clear incentive to maximize risk-adjusted profitability ${ }^{58}$. Empirically testing the risk sensitivity of SND spreads using publicly available information such as ratings, accounting and market variables represents a test of condition 2. As such, it is a test of just one of the necessary conditions for market discipline to be effective. An implicit assumption often made by previous empirical studies is that publicly available information is an adequately and timely reflection of banks' changing risk profiles. This represents a strong assumption as major international banks become involved in activities that rapidly change over time. Furthermore, the fact that private investors can discriminate between different banks does not necessarily mean that they can discipline their risk taking behavior. Indeed, the risk-sensitivity of SND spreads represents a necessary, but not sufficient, condition for market discipline to be effective. Further research of the "second generation" type, addressing the "sufficiency question", is therefore needed for the European banking industry.

Finally, the result concerning European public banks' lower SND spreads has important implications for capital regulation. Indeed, under the current capital adequacy framework SND are forms of indebtedness that may qualify as tier 2 capital when the instrument has a maturity of at least five years ${ }^{59}$. The implicit government subsidy enjoyed by European public banks therefore represents a violation of the "level playing field" principle that was originally set forth by the Basel Committee as one of the two main goals of the 1988 Capital Accord ${ }^{60}$.

\footnotetext{
${ }^{57}$ This test has been done for France, Germany and the UK only, as for the other countries not enough issues and/or accounting variables were available.

${ }^{58}$ This in turn may occur because of public ownership or management-shareholders agency type problems.

${ }^{59}$ A maturity of at least two years is allowed for tier 3 capital, which only qualifies for market risk capital requirements purposes.

${ }_{60}$ As an example, at the end of 1998 the twelve German Landesbanks had subordinated debt outstanding of approximately U.S. $\$ 20$ billion. The estimated 50 basis points interest rate subsidy (see Table 8, column 2) therefore amounts to approximately U.S.\$100 million in lower cost of capital.
} 


\section{REFERENCES}

Avery, Robert B., Terrence M. Belton and Michael A. Goldberg, 1988, "Market Discipline in Regulating Bank Risk: New Evidence from the Capital Markets", Journal of Money, Credit and Banking 20, 597-610.

Basel Committee on Banking Supervision, 2000, A New Capital Adequacy Framework: Pillar 3, Market Discipline, Consultative Paper n. 65, January.

Basel Committee on Banking Supervision, 1999a, Sound Practices for Loan Accounting and Disclosure, Consultative Paper n. 55, July.

Basel Committee on Banking Supervision, 1999b, Best Practices for Credit Risk Disclosure, Consultative Paper n. 53, July.

Basel Committee on Banking Supervision, 1999c, A New Capital Adequacy Framework, Consultative Paper n. 50, June.

Basel Committee on Banking Supervision, 1999d, Capital Requirements and Bank Behavior: the Impact of the Basle Accord, Working Paper n. 1, April.

Basel Committee on Banking Supervision, 1996, Amendment to the capital accord to incorporate market risks, Consultative Paper n. 24, January.

Basel Committee on Banking Supervision, 1988, International Convergence of Capital Measurement and Capital Standards, July.

Bliss, Robert R. and Mark J. Flannery, 2000, "Market Discipline in the Governance of U.S. Bank Holding Companies: Monitoring vs. Influencing", Working Paper Series 2000-03, Federal Reserve Bank of Chicago.

Bruni, Franco and Francesco Paternò, 1995, "Market Discipline of Banks' Riskiness: A Study of Selected Issues", Journal of Financial Services Research, December, 303-325.

Cantor, Richard and Frank Packer, 1994, "The Credit Rating Industry", Federal Reserve Bank of New York Quarterly Bulletin 19, n. 2, Summer-Fall, 1-26.

Carey, Mark and William F. Treacy, 1998, "Credit Risk Rating at Large U.S. Banks", Federal Reserve Bulletin 84, November.

Carrington, Tim, 1984, “U.S. won't let 11 biggest banks in nation fail”, Wall Street Journal, September 20, p. A2.

Covitz, Daniel M., Diana Hancock and Myron Kwast, 2000, "Mandatory Subordinated Debt: Would Banks Face More Market Discipline?", Board of Governors of the Federal Reserve System.

Board of Governors of the Federal Reserve System, 1999, Using Subordinated Debt as an Instrument of Market Discipline, Staff Study 172, December.

Flannery Mark J. and Sorin M. Sorescu, 1996, "Evidence of Bank Market Discipline in Subordinated Debenture Yields: 1983-1991”, The Journal of Finance 51, 1347-1377.

Flannery, Mark J., 1998, “Using Market Information in prudential Bank Supervision: a Review of the U.S. Empirical Evidence", Journal of Money, Credit and Banking 30, 273-305. 
Gorton, Gary and Anthony Santomero, 1990, "Market discipline and bank subordinated debt", Journal of Money, Credit and Banking 22, 203-212.

Jagtiani, Julapa, George Kaufman and Catharine Lemieux, 1999, "Do Markets Discipline Banks and Bank Holding Companies? Evidence from Debt Pricing", paper presented at the American Economic Association meeting, January 3.

Levich, Richard, 1998, International Financial Markets: Prices and Policies, McGraw Hill.

Merton, Robert C., 1974, "On the pricing of corporate debt: The risk structure of interest rates", Journal of Finance 29, 449-470.

Morgan, Donald P. and Kevin J. Stiroh, 1999, "Bond Market Discipline of Banks: Is the Market Tough Enough?", Working paper, Federal Reserve Bank of New York, December.

Sironi, Andrea, 2000, "An Analysis of European Banks Subordinated Debt Issues and Its Implications for a Mandatory Subordinated Debt Policy", paper presented at a Federal Reserve Board seminar, July 12.

The Economist, 2000, Public-sector banks: To court, April 15 ${ }^{\text {th }}, 80-81$. 
Table 1 - Sample descriptive statistics - Distribution by rating classes

\begin{tabular}{|c|c|c|c|c|c|c|c|c|c|}
\hline \multicolumn{10}{|c|}{ Panel A: Moody's/Standard \& Poor's issue ratings at launch } \\
\hline & & & \multicolumn{5}{|c|}{ Spread (b.p.) } & \multicolumn{2}{|c|}{ Amount (USND m) } \\
\hline & Rating Class & N. of issues & Mean & Median & Minimum & Maximum & Std. Dev. & Total & Average \\
\hline 1 & AAA/Aaa & 17 & 43.56 & 42.00 & 17.00 & 102.00 & 22.56 & 4,569 & 269 \\
\hline 2 & $\mathrm{AA}+/ \mathrm{Aa} 1$ & 40 & 43.65 & 39.00 & 1.00 & 125.00 & 22.93 & 9,870 & 247 \\
\hline 3 & $\mathrm{AA} / \mathrm{Aa} 2$ & 45 & 63.84 & 60.00 & 15.00 & 175.00 & 29.49 & 13,605 & 302 \\
\hline 4 & AA-/Aa3 & 73 & 81.98 & 85.00 & 20.00 & 185.00 & 36.45 & 23,459 & 321 \\
\hline 5 & $A+/ A 1$ & 43 & 82.57 & 86.00 & 13.80 & 146.00 & 27.26 & 11,069 & 257 \\
\hline 6 & $\mathrm{~A} / \mathrm{A} 2$ & 34 & 94.87 & 92.00 & 31.00 & 223.00 & 44.47 & 8,745 & 257 \\
\hline 7 & A-/A3 & 34 & 96.03 & 93.50 & 45.00 & 280.00 & 44.93 & 5,716 & 168 \\
\hline 8 & BBB+/Baa1 & 4 & 76.25 & 60.00 & 45.00 & 140.00 & 43.09 & 522 & 131 \\
\hline & Total & 290 & 74.79 & 69.50 & 1.00 & 280.00 & 38.46 & 77,555 & 267 \\
\hline \multicolumn{10}{|c|}{ Pane1 B: Moody's/Standard \& Poor's issuer ratings at launch } \\
\hline & & & \multicolumn{5}{|c|}{$S p$} & \multicolumn{2}{|c|}{ Amount (USND m) } \\
\hline & Rating Class & N. of issues & Mean & Median & Minimum & Maximum & Std. Dev. & Total & Average \\
\hline 1 & AAA/Aaa & 36 & 44.71 & 43.50 & 15.00 & 105.00 & 21.02 & 9,113 & 253 \\
\hline 2 & $\mathrm{AA}+/ \mathrm{Aa} 1$ & 68 & 60.94 & 54.00 & 1.00 & 175.00 & 32.38 & 19,834 & 292 \\
\hline 3 & AA/Aa2 & 69 & 72.61 & 67.00 & 15.00 & 185.00 & 35.54 & 22,829 & 331 \\
\hline 4 & AA-/Aa3 & 62 & 90.20 & 91.25 & 13.80 & 161.00 & 30.57 & 15,196 & 245 \\
\hline 5 & $A+/ A 1$ & 16 & 103.00 & 103.50 & 43.00 & 158.00 & 34.33 & 3,734 & 233 \\
\hline 6 & $\mathrm{~A} / \mathrm{A} 2$ & 38 & 95.46 & 89.00 & 42.00 & 280.00 & 49.65 & 6,764 & 178 \\
\hline 7 & A-/A3 & 1 & 59.00 & 59.00 & 59.00 & 59.00 & 0.00 & 84 & 84 \\
\hline & Total & 290 & 74.79 & 69.50 & 1.00 & 280.00 & 38.46 & 77,555 & 267 \\
\hline \multicolumn{10}{|c|}{ Panel C: Moody's Financial Strength/Fitch IBCA individual issuer ratings at launch } \\
\hline & & & \multicolumn{5}{|c|}{ Spread (b.p.) } & \multicolumn{2}{|c|}{ Amount (USND m) } \\
\hline & Rating Class & N. of issues & Mean & Median & Minimum & Maximum & Std. Dev. & Total & Average \\
\hline 1 & A & 27 & 60.96 & 48.00 & 15.00 & 152.00 & 33.64 & 8,692 & 322 \\
\hline 2 & $B+, A / B$ & 83 & 69.70 & 60.00 & 1.00 & 175.00 & 33.86 & 27,731 & 334 \\
\hline 3 & $B$ & 85 & 83.96 & 89.00 & 13.80 & 185.00 & 37.73 & 23,170 & 273 \\
\hline 4 & $\mathrm{C}+, \mathrm{B} / \mathrm{C}$ & 47 & 63.64 & 50.00 & 19.00 & 168.00 & 34.73 & 9,656 & 205 \\
\hline 5 & $\mathrm{C}$ & 41 & 87.87 & 77.00 & 38.00 & 280.00 & 48.33 & 6,319 & 154 \\
\hline 6 & $D+, C / D$ & 7 & 75.57 & 89.00 & 17.00 & 125.00 & 36.90 & 1,987 & 284 \\
\hline & Total & 290 & 74.79 & 69.50 & 1.00 & 280.00 & 38.46 & 77,555 & 279 \\
\hline
\end{tabular}


Table 2 - Sample descriptive statistics - Distribution by year and country

\begin{tabular}{|c|c|c|c|c|c|c|c|c|c|c|c|c|}
\hline \multicolumn{13}{|c|}{ Panel A: Distribution by year } \\
\hline & & & \multicolumn{6}{|c|}{ Average Rating at Launch } & \multicolumn{2}{|c|}{ Spread (b.p.) } & \multicolumn{2}{|c|}{ Amount (USND m) } \\
\hline Year & \multicolumn{2}{|c|}{ N. of issues } & $\begin{array}{c}\text { Moody's/S } \\
\text { Issue }\end{array}$ & & $\begin{array}{l}\text { Moody } \\
\text { Iss }\end{array}$ & $\begin{array}{l}\text { y's/S\&P } \\
\text { suer }\end{array}$ & & $\begin{array}{l}\text { IBFS/FII } \\
\text { Issuer }\end{array}$ & Mean & $\begin{array}{l}\text { Std. } \\
\text { Dev. }\end{array}$ & Total & Average \\
\hline 1991 & \multicolumn{2}{|l|}{4} & \multicolumn{2}{|l|}{4.1} & \multicolumn{2}{|c|}{2.8} & & 2.8 & 162.8 & 22.1 & 735 & 184 \\
\hline 1992 & \multicolumn{2}{|c|}{10} & \multicolumn{2}{|l|}{3.4} & \multicolumn{2}{|c|}{2.6} & & 3.8 & 57.5 & 52.5 & 1,478 & 148 \\
\hline 1993 & \multicolumn{2}{|c|}{31} & \multicolumn{2}{|l|}{3.3} & \multicolumn{2}{|c|}{2.6} & & 3.1 & 68.6 & 42.2 & 7,627 & 246 \\
\hline 1994 & \multicolumn{2}{|c|}{18} & \multicolumn{2}{|l|}{4.3} & \multicolumn{2}{|c|}{3.6} & & 3.4 & 73.9 & 33.0 & 4,085 & 227 \\
\hline 1995 & \multicolumn{2}{|c|}{37} & \multicolumn{2}{|l|}{4.5} & \multicolumn{2}{|c|}{3.4} & & 2.9 & 69.3 & 22.1 & 9,096 & 246 \\
\hline 1996 & \multicolumn{2}{|c|}{46} & \multicolumn{2}{|l|}{4.6} & \multicolumn{2}{|c|}{3.6} & & 3.1 & 64.1 & 25.0 & 12,619 & 274 \\
\hline 1997 & \multicolumn{2}{|c|}{46} & \multicolumn{2}{|l|}{3.7} & \multicolumn{2}{|c|}{3.0} & & 3.0 & 45.6 & 15.4 & 11,229 & 244 \\
\hline 1998 & \multicolumn{2}{|c|}{27} & 4.7 & & & 3.6 & & 3.3 & 68.4 & 29.2 & 6,830 & 253 \\
\hline 1999 & 52 & & 4.4 & & & 3.8 & & 3.3 & 109.7 & 41.6 & 19,097 & 367 \\
\hline 2000: Q1 & 19 & & 4.7 & & & 4.1 & & 4.1 & 97.4 & 20.4 & 4,759 & 250 \\
\hline Total & 29 & & 4.2 & & & 3.3 & & 3.2 & 74.8 & 38.46 & 77,555 & 267 \\
\hline & & & & Pan & B: Dist & tribution 1 & y ce & ountry & & & & \\
\hline & & $\begin{array}{r}\text { Issues } \\
\mathrm{B}\end{array}$ & $\begin{array}{l}\text { by Public } \\
\text { anks }\end{array}$ & & verage & Rating a & $\mathrm{t} \mathrm{La}$ & aunch & Sprea & (b.p.) & $\begin{array}{l}\text { Am } \\
\text { (USN }\end{array}$ & $\begin{array}{l}\text { unt } \\
D \mathrm{~m} \text { ) }\end{array}$ \\
\hline Country & \begin{tabular}{|c|} 
N. of \\
issues
\end{tabular} & Numbe & $\%$ & $\begin{array}{l}\mathrm{Mc} \\
\mathrm{S} \&\end{array}$ & $\begin{array}{l}\text { Ddy's- } \\
\text { Issue }\end{array}$ & $\begin{array}{l}\text { Moody' } \\
\text { S\&P IsS }\end{array}$ & & \begin{tabular}{|l|} 
MBFS/F \\
II Issuer
\end{tabular} & Mean & $\begin{array}{l}\text { Std. } \\
\text { Dev. }\end{array}$ & Total & Avg. \\
\hline Austria & 6 & 5 & $83.3 \%$ & & 3.4 & 2.6 & & 4.8 & 63.3 & 29.4 & 1,348 & 225 \\
\hline Belgium & 12 & 1 & $8.3 \%$ & & 4.2 & 3.4 & & 2.9 & 54.1 & 38.3 & 1,348 & 112 \\
\hline Denmark & 4 & 0 & $0.0 \%$ & & 5.5 & 4.3 & & 3.0 & 103.8 & 10.3 & 1,000 & 250 \\
\hline Finland & 3 & 0 & $0.0 \%$ & & 7.0 & 6.0 & & 5.7 & 104.3 & 26.6 & 800 & 267 \\
\hline France & 36 & 6 & $16.7 \%$ & & 5.6 & 4.8 & & 4.1 & 58.4 & 33.2 & 6,608 & 184 \\
\hline Germany & 75 & 38 & $50.7 \%$ & & 2.8 & 2.4 & & 3.6 & 60.4 & 38.1 & 16,239 & 217 \\
\hline Great Br. & 63 & 0 & $0.0 \%$ & & 4.8 & 3.5 & & 2.6 & 107.5 & 38.3 & 24,037 & 382 \\
\hline Ireland & 2 & 0 & $0.0 \%$ & & 5.5 & 4.8 & & 3.0 & 95.0 & 0.0 & 746 & 373 \\
\hline Italy & 3 & 0 & $0.0 \%$ & & 0.2 & 5.5 & & 4.2 & 116.0 & 4.6 & 1,145 & 382 \\
\hline Lux. & 1 & 0 & $0.0 \%$ & & 5.0 & 4.0 & & 3.0 & 83.0 & 0.0 & 51 & 51 \\
\hline Neth. & 32 & 0 & $0.0 \%$ & & 4.0 & 3.3 & & 2.7 & 62.2 & 22.5 & 10,341 & 323 \\
\hline Spain & 21 & 0 & $0.0 \%$ & & 5.1 & 4.2 & & 3.1 & 86.7 & 25.2 & 5,831 & 278 \\
\hline Sweden & 2 & 0 & $0.0 \%$ & & 0.0 & 6.0 & & 4.5 & 90.0 & 25.5 & 368 & 184 \\
\hline Switz. & 30 & 0 & $0.0 \%$ & & 3.8 & 2.6 & & 2.7 & 64.0 & 24.0 & 7,692 & 256 \\
\hline Total & 290 & 50 & $17.2 \%$ & & 4.2 & 3.4 & & 3.2 & 74.8 & 38.5 & 77,555 & 267 \\
\hline
\end{tabular}


Table 3 - Samples descriptive statistics: accounting variables - distribution by country

\begin{tabular}{|c|c|c|c|c|c|c|c|c|c|c|c|c|}
\hline \multirow[t]{2}{*}{ Country } & \multicolumn{3}{|c|}{ Number of issues } & \multirow[t]{2}{*}{ TA } & \multirow[t]{2}{*}{ ROA (\%) } & \multirow[t]{2}{*}{ LEV } & \multirow{2}{*}{$\begin{array}{c}\text { NL/TA } \\
(\%)\end{array}$} & \multirow{2}{*}{$\begin{array}{l}\text { LLR/GL } \\
(\%)\end{array}$} & \multirow{2}{*}{$\begin{array}{c}\text { NPL/GL } \\
(\%)\end{array}$} & \multirow{2}{*}{$\begin{array}{c}\text { ROA }^{*} \text { LEV } \\
(\%)\end{array}$} & \multirow{2}{*}{$\begin{array}{l}\text { LLR*LEV }^{*} \\
(\%)\end{array}$} & \multirow{2}{*}{$\begin{array}{c}\text { NPL*LEV } \\
(\%)\end{array}$} \\
\hline & Sample A & Sample B & Sample C & & & & & & & & & \\
\hline Austria & 6 & 5 & 0 & 0.15 & 0.27 & 25.00 & 49 & 3.93 & NA & 6.63 & 98.87 & NA \\
\hline Belgium & 10 & 0 & 0 & 0.30 & 0.49 & 27.51 & 42 & NA & NA & 13.68 & NA & NA \\
\hline Denmark & 4 & 4 & 4 & 0.17 & 0.77 & 17.24 & 51 & 4.71 & 1.94 & 13.06 & 79.89 & 32.37 \\
\hline Finland & 3 & 0 & 0 & 0.10 & 0.08 & 21.74 & 55 & NA & NA & 1.87 & NA & NA \\
\hline France & 35 & 35 & 22 & 0.50 & 0.20 & 30.75 & 42 & 4.92 & 8.43 & 6.32 & 153.28 & 276.95 \\
\hline Germany & 74 & 26 & 0 & 0.43 & 0.22 & 35.85 & 58 & 2.80 & NA & 7.46 & 81.25 & NA \\
\hline Great Britain & 63 & 63 & 51 & 0.35 & 0.79 & 21.19 & 60 & 2.33 & 4.68 & 16.45 & 49.46 & 102.66 \\
\hline Ireland & 2 & 2 & 1 & 0.12 & 1.46 & 16.02 & 66 & 1.36 & 1.21 & 23.34 & 21.82 & 19.16 \\
\hline Italy & 3 & 3 & 2 & 0.18 & 0.66 & 16.00 & 60 & 3.28 & 5.92 & 10.52 & 54.28 & NA \\
\hline Luxembourg & 0 & 0 & 0 & NA & NA & NA & NA & NA & NA & 27.42 & NA & NA \\
\hline Netherland & 32 & 0 & 0 & 0.51 & 0.51 & 21.27 & 59 & NA & NA & 10.63 & NA & NA \\
\hline Spain & 20 & 20 & 13 & 0.29 & 0.72 & 16.84 & 42 & 3.83 & 4.00 & 11.75 & 66.20 & 71.23 \\
\hline Sweden & 2 & 1 & 1 & 0.19 & 0.08 & 20.79 & 69 & 1.20 & 2.85 & 1.54 & 29.48 & 69.83 \\
\hline Switzerland & 30 & 30 & 0 & 0.64 & 0.25 & 20.92 & 45 & 5.24 & NA & 3.83 & 98.30 & NA \\
\hline Total & 285 & 189 & 94 & & & & & & & & & \\
\hline Sample Avg. & & & & 0.41 & 0.45 & 26.04 & 54 & 3.59 & 5.32 & 9.97 & 84.57 & 134.83 \\
\hline Sample St.dev. & & & & 0.26 & 0.32 & 10.29 & 14 & 2.03 & 3.06 & 6.53 & 57.90 & 109.30 \\
\hline
\end{tabular}


Table 4 - Sample issuing banks

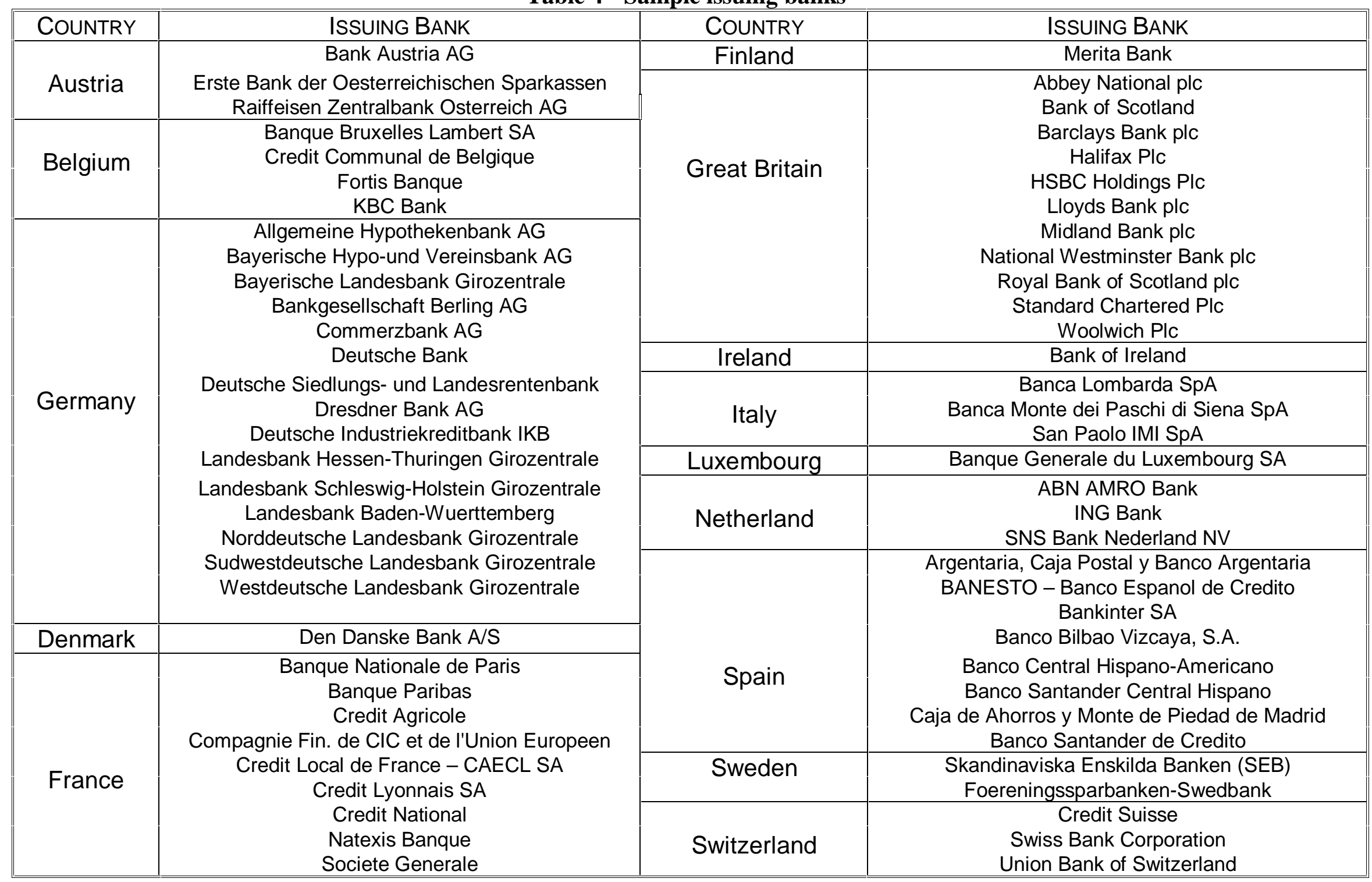


Table 5 - Regression results: issue and issuer ratings

\begin{tabular}{|c|c|c|c|}
\hline & $\begin{array}{c}\text { Moody's-S\&P Issue } \\
\text { (1) }\end{array}$ & $\begin{array}{c}\text { Moody's-S\&P Issuer } \\
\text { (3) }\end{array}$ & $\begin{array}{c}\text { MBFS-FII } \\
\text { (3) }\end{array}$ \\
\hline Rating $=2$ & $\begin{array}{c}18.606^{* * * *} \\
(6.582)\end{array}$ & $\begin{array}{c}6.795 \\
(4.840)\end{array}$ & $\begin{array}{l}-4.968 \\
(5.918)\end{array}$ \\
\hline Rating $=3$ & $\begin{array}{l}28.331 * * * \\
(7.057)\end{array}$ & $\begin{array}{l}17.421 * * * \\
(5.138)\end{array}$ & $\begin{array}{c}7.337 \\
(6.078)\end{array}$ \\
\hline Rating $=4$ & $\begin{array}{l}37.436 * * * \\
(6.768)\end{array}$ & $\begin{array}{l}33.130 * * * \\
(5.559)\end{array}$ & $\begin{array}{c}8.279 \\
(6.337)\end{array}$ \\
\hline Rating $=5$ & $\begin{array}{l}49.633 * * * \\
(7.507)\end{array}$ & $\begin{array}{l}45.393 * * * \\
(7.252)\end{array}$ & $\begin{array}{l}27.074 * * * \\
(7.057)\end{array}$ \\
\hline Rating $=6$ & $\begin{array}{l}53.486 * * * \\
(7.567)\end{array}$ & $\begin{array}{l}55.757 * * * \\
(6.135)\end{array}$ & $\begin{array}{c}11.781 \\
(11.315)\end{array}$ \\
\hline Rating $=7$ & $\begin{array}{l}73.246 * * * \\
(7.628)\end{array}$ & $\begin{array}{l}59.756 * * * \\
(22.867)\end{array}$ & - \\
\hline Rating $=8$ & $\begin{array}{l}74.734 * * * \\
(13.397)\end{array}$ & - & - \\
\hline AMOUNT & $\begin{array}{l}5.534 * * \\
(2.284)\end{array}$ & $\begin{array}{l}5.555^{* *} \\
(2.293)\end{array}$ & $\begin{array}{l}1.001 \\
(2.580)\end{array}$ \\
\hline MATU & $\begin{array}{l}0.994 * * * \\
(0.194)\end{array}$ & $\begin{array}{l}1.088 * * * \\
(0.195)\end{array}$ & $\begin{array}{l}0.916 * * * \\
(0.221)\end{array}$ \\
\hline DFL & $\begin{array}{l}10.571 \\
(9.652)\end{array}$ & $\begin{array}{l}14.817 \\
(9.695)\end{array}$ & $\begin{array}{l}22.296 * * \\
(11.063)\end{array}$ \\
\hline EUR & $\begin{array}{c}5.221 \\
(8.705)\end{array}$ & $\begin{array}{c}8.271 \\
(8.694)\end{array}$ & $\begin{array}{l}14.672 \\
(9.892)\end{array}$ \\
\hline FFR & $\begin{array}{l}3.985 \\
(9.751)\end{array}$ & $\begin{array}{c}4.317 \\
(9.811)\end{array}$ & $\begin{array}{c}9.310 \\
(11.134)\end{array}$ \\
\hline STG & $\begin{array}{l}30.098 * * * \\
(9.209)\end{array}$ & $\begin{array}{l}30.426 * * * \\
(9.265)\end{array}$ & $\begin{array}{c}33.800 * * * \\
(10.562)\end{array}$ \\
\hline USD & $\begin{array}{l}28.234 * * * \\
(8.944)\end{array}$ & $\begin{array}{l}31.425 * * * \\
(8.979)\end{array}$ & $\begin{array}{l}39.658 * * * \\
(10.199)\end{array}$ \\
\hline DEM & $\begin{array}{l}11.656 \\
(9.986)\end{array}$ & $\begin{array}{l}15.991 \\
(9.964)\end{array}$ & $\begin{array}{l}26.704 * * \\
(11.277)\end{array}$ \\
\hline GER & $\begin{array}{c}6.446 \\
(5.207)\end{array}$ & $\begin{array}{c}2.490 \\
(5.132)\end{array}$ & $\begin{array}{l}-15.586 * * * \\
(5.526)\end{array}$ \\
\hline SPA & $\begin{array}{c}3.823 \\
(6.267)\end{array}$ & $\begin{array}{c}2.721 \\
(6.317)\end{array}$ & $\begin{array}{c}5.492 \\
(7.260)\end{array}$ \\
\hline FRA & $\begin{array}{l}-7.963 \\
(5.934)\end{array}$ & $\begin{array}{l}-8.012 \\
(5.964)\end{array}$ & $\begin{array}{l}-8.390 \\
(6.862)\end{array}$ \\
\hline UK & $\begin{array}{c}8.974 \\
(5.671)\end{array}$ & $\begin{array}{l}13.889 * * \\
(5.654)\end{array}$ & $\begin{array}{l}18.624 * * * \\
(6.521)\end{array}$ \\
\hline NET & $\begin{array}{c}0.726 \\
(6.293)\end{array}$ & $\begin{array}{c}2.081 \\
(6.326)\end{array}$ & $\begin{array}{l}-3.860 \\
(7.182)\end{array}$ \\
\hline SWI & $\begin{array}{l}-0.277 \\
(6.037)\end{array}$ & $\begin{array}{c}4.607 \\
(6.085)\end{array}$ & $\begin{array}{l}-6.293 \\
(6.979)\end{array}$ \\
\hline Constant & $\begin{array}{r}42.044 * * \\
(17.995)\end{array}$ & $\begin{array}{c}56.036 * * * \\
(17.572)\end{array}$ & $\begin{array}{l}86.075 * * * \\
(20.817)\end{array}$ \\
\hline $\mathrm{N}$ & 290 & 290 & 290 \\
\hline $\mathrm{R}^{2}$ & 0.724 & 0.719 & 0.635 \\
\hline Adjusted $\mathrm{R}^{2}$ & 0.692 & 0.688 & 0.569 \\
\hline $\mathrm{Fa}$ & $22.691 * * *$ & $22.959 * * *$ & $15.622 * * *$ \\
\hline $\mathrm{Fb}$ & $11.700 * * *$ & $12.561 * * *$ & $3.877 * * *$ \\
\hline
\end{tabular}

$* * *, * *$, and $*$ indicate statistical significance at the $1 \%, 5 \%$ and $10 \%$ level, respectively. Standard errors in parenthesis. $\mathrm{Fb}$ denotes the calculated F-statistic for the null hypothesis that the coefficients on the subset of rating dummy variables used to proxy default risk jointly equal zero. 
Table 6 - Regression results: issuer FII and MBFS ratings

\begin{tabular}{|c|c|c|c|}
\hline & $\begin{array}{l}\text { Entire sample without } \\
\text { PUBLIC dummy } \\
\text { (1) }\end{array}$ & $\begin{array}{l}\text { Entire Sample with } \\
\text { PUBLIC dummy } \\
\text { (2) }\end{array}$ & $\begin{array}{c}\text { Private banks } \\
\text { Sub-sample } \\
\text { (3) }\end{array}$ \\
\hline Rating $=2$ & -5.450 & 1.509 & 3.845 \\
\hline & $(6.041)$ & $(5.480)$ & $(5.579)$ \\
\hline Rating $=3$ & $\begin{array}{c}6.773 \\
(6.228)\end{array}$ & $\begin{array}{c}12.432 * * \\
(5.623)\end{array}$ & $\begin{array}{c}14.001 * * \\
(5.965)\end{array}$ \\
\hline Rating $=4$ & $\begin{array}{c}7.213 \\
(6.774)\end{array}$ & $\begin{array}{c}27.067 * * * \\
(6.544)\end{array}$ & $\begin{array}{c}31.689 * * * \\
(7.787)\end{array}$ \\
\hline Rating $=5$ & $\begin{array}{c}25.439 * * * \\
(7.869)\end{array}$ & $\begin{array}{c}34.504 * * * \\
(7.138)\end{array}$ & $\begin{array}{c}39.536^{* * *} \\
(7.722)\end{array}$ \\
\hline Rating $=6$ & $\begin{array}{c}9.832 \\
(11.983)\end{array}$ & $\begin{array}{c}24.894 * * * \\
(10.894)\end{array}$ & $\begin{array}{c}29.374 * * \\
(14.752)\end{array}$ \\
\hline AMOUNT & $\begin{array}{c}1.324 \\
(2.718)\end{array}$ & $\begin{array}{c}3.196 \\
(2.445)\end{array}$ & $\begin{array}{l}4.242 \\
(2.699)\end{array}$ \\
\hline MATU & $\begin{array}{c}0.916 * * * \\
(0.224)\end{array}$ & $\begin{array}{c}0.898 * * * \\
(0.200)\end{array}$ & $\begin{array}{c}0.858 * * * \\
(0.210)\end{array}$ \\
\hline DFL & $\begin{array}{l}23.017 * \\
(11.741)\end{array}$ & $\begin{array}{c}9.940 \\
(10.641)\end{array}$ & $\begin{array}{c}11.406 \\
(13.530)\end{array}$ \\
\hline EUR & $\begin{array}{c}15.364 \\
(10.536)\end{array}$ & $\begin{array}{c}7.265 \\
(9.490)\end{array}$ & $\begin{array}{c}10.355 \\
(12.118)\end{array}$ \\
\hline FFR & $\begin{array}{c}9.482 \\
(11.764)\end{array}$ & $\begin{array}{c}-1.156 \\
(10.620)\end{array}$ & $\begin{array}{c}-3.952 \\
(13.605)\end{array}$ \\
\hline STG & $\begin{array}{c}34.345^{* * *} \\
(11.256)\end{array}$ & $\begin{array}{c}32.949 * * * \\
(10.083)\end{array}$ & $\begin{array}{c}46.062 * * * \\
(13.439)\end{array}$ \\
\hline USD & $\begin{array}{c}40.415 * * * \\
(10.875)\end{array}$ & $\begin{array}{c}35.315 * * * \\
(9.760)\end{array}$ & $\begin{array}{c}36.046 * * * \\
(12.714)\end{array}$ \\
\hline DEM & $\begin{array}{c}27.201 * * \\
(11.875)\end{array}$ & $\begin{array}{c}17.580 \\
(10.703)\end{array}$ & $\begin{array}{c}18.523 \\
(13.772)\end{array}$ \\
\hline PUBLIC & - & $\begin{array}{c}-40.310 * * * \\
(5.033)\end{array}$ & - \\
\hline TA & $\begin{array}{l}-4.410 \\
(8.479)\end{array}$ & $\begin{array}{l}-10.684 \\
(7.6349)\end{array}$ & $\begin{array}{l}-8.197 \\
(8.584)\end{array}$ \\
\hline GER & $\begin{array}{c}-14.131 * * \\
(6.091)\end{array}$ & $\begin{array}{c}0.007 \\
(5.734)\end{array}$ & $\begin{array}{c}3.068 \\
(6.867)\end{array}$ \\
\hline SPA & $\begin{array}{c}5.801 \\
(7.548)\end{array}$ & $\begin{array}{c}2.609 \\
(6.772)\end{array}$ & $\begin{array}{c}5.844 \\
(7.113)\end{array}$ \\
\hline FRA & $\begin{array}{l}-6.554 \\
(7.786)\end{array}$ & $\begin{array}{l}-1.043 \\
(7.007)\end{array}$ & $\begin{array}{l}-0.256 \\
(8.241)\end{array}$ \\
\hline UK & $\begin{array}{c}19.129 * * * \\
(6.684)\end{array}$ & $\begin{array}{c}13.804 * * \\
(6.023)\end{array}$ & $\begin{array}{c}7.690 \\
(6.670)\end{array}$ \\
\hline NET & $\begin{array}{c}-2.412 \\
(7.739)\end{array}$ & $\begin{array}{l}-1.956 \\
(6.932)\end{array}$ & $\begin{array}{l}-0.885 \\
(7.512)\end{array}$ \\
\hline SWI & $\begin{array}{l}-4.273 \\
(7.967)\end{array}$ & $\begin{array}{l}-7.525 \\
(7.147)\end{array}$ & $\begin{array}{l}-8.187 \\
(7.857)\end{array}$ \\
\hline Constant & $\begin{array}{c}86.024 * * * \\
(21.361)\end{array}$ & $\begin{array}{c}80.389 * * * \\
(19.144)\end{array}$ & $\begin{array}{c}65.769 * * * \\
(21.387)\end{array}$ \\
\hline $\mathrm{N}$ & 290 & 290 & 240 \\
\hline $\mathrm{R}^{2}$ & 0.632 & 0.706 & 0.714 \\
\hline Adjusted $\mathrm{R}^{2}$ & 0.590 & 0.672 & 0.674 \\
\hline $\mathrm{Fa}$ & $15.169 * * *$ & $20.419 * * *$ & $17.826 * * *$ \\
\hline $\mathrm{Fb}$ & $4.003 * * *$ & $4.003 * * *$ & $4.245 * * *$ \\
\hline
\end{tabular}

$* * *, * *$, and * indicate statistical significance at the $1 \%, 5 \%$ and $10 \%$ level, respectively. Standard errors in parenthesis. $\mathrm{Fb}$ denotes the calculated F-statistic for the null hypothesis that the coefficients on the subset of rating dummy variables used to proxy bank risk jointly equal zero. 
Table 7 - Regression results: different samples with control, accounting variables and MBFS-FII rating dummies

\begin{tabular}{|c|c|c|c|c|c|c|c|c|c|c|c|c|}
\hline & \multicolumn{4}{|c|}{ SAMPLE A } & \multicolumn{4}{|c|}{ SAMPLE B } & \multicolumn{4}{|c|}{ SAMPLE C } \\
\hline & $\begin{array}{c}\text { Control } \\
\text { only }\end{array}$ & $\begin{array}{c}\text { Control } \\
\& \\
\text { Rating }\end{array}$ & $\begin{array}{c}\text { Control } \\
\& \\
\text { Acc.ing }\end{array}$ & All & $\begin{array}{c}\text { Control } \\
\text { only }\end{array}$ & $\begin{array}{c}\text { Control } \\
\& \\
\text { Rating }\end{array}$ & $\begin{array}{c}\text { Control } \\
\& \\
\text { Acc.ting }\end{array}$ & All & $\begin{array}{c}\text { Control } \\
\text { only }\end{array}$ & $\begin{array}{c}\text { Control } \\
\& \\
\text { Rating }\end{array}$ & $\begin{array}{c}\text { Control } \\
\& \\
\text { Acc.ting }\end{array}$ & All \\
\hline $\mathrm{TA}$ & $\begin{array}{c}-32.472 * * * \\
(7392)\end{array}$ & $\begin{array}{l}-12.437 \\
(7.777)\end{array}$ & $\begin{array}{c}-25.840 * * * \\
(8.460)\end{array}$ & $\begin{array}{c}-0.691 \\
(9.341)\end{array}$ & $\begin{array}{c}-34.973 * * * \\
(10.400)\end{array}$ & $\begin{array}{c}-4.819 \\
(10.213)\end{array}$ & $\begin{array}{c}-36.922 * * * \\
(11.580)\end{array}$ & $\begin{array}{c}0.981 \\
(11.788)\end{array}$ & $\begin{array}{c}-59.412 * * * \\
(15.473)\end{array}$ & $\begin{array}{c}-27.904 \\
(17.138)\end{array}$ & $\begin{array}{c}-63.317 * * * \\
(15.938)\end{array}$ & $\begin{array}{c}-22.944 \\
(19.760)\end{array}$ \\
\hline Public & $\begin{array}{c}-32.343 * * * \\
(5.004) \\
\end{array}$ & $\begin{array}{c}-41.189 * * * \\
(5.164)\end{array}$ & $\begin{array}{c}-33.425 * * * \\
(5.892) \\
\end{array}$ & $\begin{array}{c}-36.590 * * * \\
(5.906)\end{array}$ & $\begin{array}{c}-36.199 * * * \\
(10.010)\end{array}$ & $\begin{array}{c}-38.895 * * * \\
(9.447) \\
\end{array}$ & $\begin{array}{c}-40.947 * * * \\
(10.720)\end{array}$ & $\begin{array}{c}-36.151^{* * *} * \\
(9.918)\end{array}$ & $\begin{array}{c}-19.281 \\
(15.337) \\
\end{array}$ & $\begin{array}{c}-18.198 \\
(15.067) \\
\end{array}$ & $\begin{array}{c}0.808 \\
(17.561) \\
\end{array}$ & $\begin{array}{c}-24.343 \\
(19.809) \\
\end{array}$ \\
\hline Rating $=2$ & - & $\begin{array}{c}1.353 \\
(5.479) \\
\end{array}$ & - & $\begin{array}{c}5.476 \\
(5.806) \\
\end{array}$ & - & $\begin{array}{c}5.268 \\
(6.308) \\
\end{array}$ & - & $\begin{array}{c}6.282 \\
(6.598) \\
\end{array}$ & - & $\begin{array}{l}10.818 \\
(7.426)\end{array}$ & - & $\begin{array}{c}10.300 \\
(10.549)\end{array}$ \\
\hline Rating $=3$ & - & $\begin{array}{c}12.874 * * \\
(5.649)\end{array}$ & - & $\begin{array}{c}14.980 * * * \\
(5.767)\end{array}$ & - & $\begin{array}{c}19.015^{* * * *} \\
(6.575)\end{array}$ & - & $\begin{array}{c}18.952 * * * \\
(6.764)\end{array}$ & - & $\begin{array}{c}16.217^{* *} \\
(7.764)\end{array}$ & - & $\begin{array}{c}16.158 \\
(10.025)\end{array}$ \\
\hline Rating $=4$ & - & $\begin{array}{c}27.072 * * * \\
(6.644)\end{array}$ & - & $\begin{array}{c}29.352 * * * \\
(6.948) \\
\end{array}$ & - & $\begin{array}{c}42.611 * * * \\
(8.631) \\
\end{array}$ & - & $\begin{array}{c}41.067 * * * * \\
(9.048)\end{array}$ & - & $\begin{array}{c}44.258 * * * \\
(11.451)\end{array}$ & - & $\begin{array}{c}47.752 * * * \\
(15.874)\end{array}$ \\
\hline Rating $=5$ & - & $\begin{array}{c}35.108 * * * \\
(7.230)\end{array}$ & - & $\begin{array}{c}39.684 * * * \\
(8.082) \\
\end{array}$ & - & $\begin{array}{c}52.520 * * * \\
(8.809)\end{array}$ & - & $\begin{array}{c}58.809 * * * \\
(10.030)\end{array}$ & - & $\begin{array}{c}44.583 * * * \\
(10.780) \\
\end{array}$ & - & $\begin{array}{c}48.123^{* * * *} \\
(16.836)\end{array}$ \\
\hline Rating $=6$ & - & $\begin{array}{c}32.755^{* * * *} \\
(11.642)\end{array}$ & - & $\begin{array}{c}36.245^{* * * *} \\
(11.909)\end{array}$ & - & $\begin{array}{c}32.895 \\
(25.054)\end{array}$ & - & $\begin{array}{c}94.737 * * * \\
(32.370)\end{array}$ & - & $\begin{array}{c}31.652 \\
(20.835)\end{array}$ & - & $\begin{array}{c}92.712 * * \\
(42.998)\end{array}$ \\
\hline $\mathrm{ROA}$ & - & - & $\begin{array}{c}-8.113 \\
(16.653)\end{array}$ & $\begin{array}{c}17.546 \\
(15.912)\end{array}$ & - & - & $\begin{array}{l}11.659 \\
(24.409\end{array}$ & $\begin{array}{c}16.403 \\
(21.820)\end{array}$ & - & - & $\begin{array}{l}53.786^{*} \\
(28.050)\end{array}$ & $\begin{array}{c}25.788 \\
(29.741)\end{array}$ \\
\hline LEV & - & - & $\begin{array}{c}0.188 \\
(0.297) \\
\end{array}$ & $\begin{array}{c}0.153 \\
(0.280) \\
\end{array}$ & - & - & $\begin{array}{c}1.088 \\
(0.767) \\
\end{array}$ & $\begin{array}{c}0.879 \\
(0.758) \\
\end{array}$ & - & - & $\begin{array}{l}2.460^{* * *} \\
(1.165)\end{array}$ & $\begin{array}{c}0.546 \\
(1.359) \\
\end{array}$ \\
\hline NLTA & - & - & $\begin{array}{c}0.223 \\
(0.160) \\
\end{array}$ & $\begin{array}{c}0.385^{* * *} \\
(0.156)\end{array}$ & - & - & $\begin{array}{l}-0.107 \\
(0.247 \\
\end{array}$ & $\begin{array}{c}0.010 \\
(0.217) \\
\end{array}$ & - & - & $\begin{array}{l}-0.520^{*} \\
(0.294)\end{array}$ & $\begin{array}{l}-0.438 \\
(0.321) \\
\end{array}$ \\
\hline LLRGL & - & - & - & - & - & - & $\begin{array}{c}7.791 \text { ** } \\
(3.869)\end{array}$ & $\begin{array}{l}9.679 * * \\
(4.185)\end{array}$ & - & - & $\begin{array}{c}4.633 \\
(5.466)\end{array}$ & $\begin{array}{c}14.656^{* * *} \\
(7.180)\end{array}$ \\
\hline NPLGL & - & - & - & - & - & - & - & - & - & - & $\begin{array}{c}1.582 \\
(5.140)\end{array}$ & $\begin{array}{l}-5.115 \\
(5.546)\end{array}$ \\
\hline ROALEV & - & - & $\begin{array}{l}-1.167 \\
(0.721)\end{array}$ & $\begin{array}{l}-0.985 \\
(0.687)\end{array}$ & - & - & $\begin{array}{l}-1.415 \\
(1.071)\end{array}$ & $\begin{array}{l}-0.803 \\
(0.981)\end{array}$ & - & - & $\begin{array}{c}-3.740^{* * *} \\
(1.303)\end{array}$ & $\begin{array}{l}-1.338 \\
(1.459)\end{array}$ \\
\hline LLRLEV & - & - & - & - & - & - & $\begin{array}{l}-0.270^{*} \\
(0.151)\end{array}$ & $\begin{array}{c}-0.437 * * \\
(0.172)\end{array}$ & - & - & $\begin{array}{l}-0.566 \\
(0.204)\end{array}$ & $\begin{array}{l}-0.608^{*} \\
(0.313)\end{array}$ \\
\hline NPLLEV & - & - & - & - & - & - & - & - & - & - & $\begin{array}{l}-0.093 \\
(0.190)\end{array}$ & $\begin{array}{c}0.143 \\
(0.198)\end{array}$ \\
\hline Constant & $\begin{array}{c}114.061 * * * \\
(18.847)\end{array}$ & $\begin{array}{c}79.987 * * * \\
(19.263)\end{array}$ & $\begin{array}{c}94.721 * * * \\
(24.877)\end{array}$ & $\begin{array}{l}59.391 * * \\
(23.609)\end{array}$ & $\begin{array}{c}133.581 * * * \\
(26.272)\end{array}$ & $\begin{array}{c}66.486 * * \\
(26.166)\end{array}$ & $\begin{array}{c}110.530 * * * \\
(40.775)\end{array}$ & $\begin{array}{c}45.587 \\
(38.373)\end{array}$ & $\begin{array}{c}80.604 * * * * \\
(30.090)\end{array}$ & $\begin{array}{l}52.141^{*} \\
(30.278)\end{array}$ & $\begin{array}{c}70.192 \\
(50.789)\end{array}$ & $\begin{array}{c}82.094 \\
(55.777)\end{array}$ \\
\hline $\mathrm{N}$ & 285 & 285 & 285 & 285 & 189 & 189 & 189 & 189 & 94 & 94 & 94 & 94 \\
\hline $\mathrm{R}^{2}$ & 0.656 & 0.709 & 0.675 & 0.724 & 0.645 & 0.738 & 0.661 & 0.756 & 0.800 & 0.854 & 0.848 & 0.883 \\
\hline Adj. $R^{2}$ & 0.622 & 0.674 & 0.636 & 0.684 & 0.592 & 0.690 & 0.597 & 0.700 & 0.741 & 0.798 & 0.779 & 0.816 \\
\hline $\mathrm{F}$ & $19.451 * * *$ & $20.329 * * *$ & $17.337 * * *$ & $18.280 * * *$ & $12.263^{* * *}$ & $15.236^{* * *}$ & $10.293 * * *$ & $13.547 * * *$ & $13.690 * * *$ & $15.115^{* * * *}$ & $12.343 * * *$ & $13.094 * * *$ \\
\hline
\end{tabular}

$* * *, * *$, and $*$ indicate statistical significance at the $1 \%, 5 \%$ and $10 \%$ level, respectively. Standard errors in parenthesis. 
Table 8 - Regression results: FII-MBFS and Moody's-S\&P issue (M-S\&P) ratings for separate time period sub-samples

\begin{tabular}{|c|c|c|c|c|c|c|c|c|c|}
\hline & $91-96$ & 97-00:Q1 & $91-96$ & 97-00:Q1 & $91-96$ & 97-00:Q1 & $91-95$ & 96-97 & "98-00:Q1 \\
\hline & FII-MBFS & FII-MBFS & M-S\&P & M-S\&P & FII-MBFS & FII-MBFS & FII-MBFS & FII-MBFS & FII-MBFS \\
\hline & $\begin{array}{c}\text { Total sample } \\
\text { (1) }\end{array}$ & $\begin{array}{c}\text { Total sample } \\
\text { (2) }\end{array}$ & $\begin{array}{c}\text { Total sample } \\
\text { (3) }\end{array}$ & $\begin{array}{c}\text { Total sample } \\
\text { (4) }\end{array}$ & $\begin{array}{c}\text { Same banks } \\
\text { only (5) }\end{array}$ & $\begin{array}{c}\text { Same banks } \\
\text { only (6) }\end{array}$ & $\begin{array}{c}\text { Total sample } \\
\text { (7) }\end{array}$ & $\begin{array}{c}\text { Total sample } \\
\text { (8) }\end{array}$ & $\begin{array}{c}\text { Total sample } \\
\text { (9) }\end{array}$ \\
\hline \multirow[t]{2}{*}{ Rating $=2$} & -19.658 & 11.606 & $16.657 * *$ & 14.600 & $-16.719 *$ & 10.934 & $-17.663^{*}$ & -4.176 & 12.352 \\
\hline & $(7.255)$ & $(8.343)$ & $(8.231)$ & $(11.450)$ & $(9.007)$ & $(8.318)$ & $(10.498)$ & $(6.471)$ & $(14.800)$ \\
\hline \multirow[t]{2}{*}{ Rating $=3$} & -6.972 & $21.484 * *$ & $25.376^{* * *}$ & $30.524 * * *$ & -5.941 & $16.851 *$ & -6.102 & 6.339 & 22.034 \\
\hline & $(7.108)$ & $(8.607)$ & $(9.461)$ & $(11.405)$ & $(9.518)$ & $(9.134)$ & (10.204) & $(7.046)$ & (14.857) \\
\hline \multirow[t]{2}{*}{ Rating $=4$} & 8.287 & $39.000 * * *$ & $23.707 * *$ & $41.157 * * *$ & 7.585 & $39.160 * * *$ & -11.245 & 14.730 & $42.735^{* *}$ \\
\hline & $(8.567)$ & $(9.961)$ & $(9.524)$ & $(10.658)$ & $(10.966)$ & $(13.499)$ & $(11.226)$ & $(9.252)$ & $(17.111)$ \\
\hline \multirow[t]{2}{*}{ Rating $=5$} & 9.986 & $51.386^{* * *}$ & $32.260 * * *$ & $53.921 * * *$ & 2.705 & $60.248 * * *$ & 7.560 & $17.971^{*}$ & $57.747 * * *$ \\
\hline & $(9.332)$ & $(10.456)$ & $(11.039)$ & $(11.629)$ & $(13.641)$ & $(12.330)$ & $(14.311)$ & $(10.514)$ & $(17.424)$ \\
\hline \multirow[t]{2}{*}{ Rating $=6$} & 0.497 & $46.676^{* *}$ & $41.925 * * *$ & $60.190 * * *$ & 9.949 & $51.921 * *$ & -14.836 & $32.739 * *$ & $54.827 * *$ \\
\hline & (12.619) & (19.489) & (10.719) & $(11.763)$ & (16.476) & $(20.831)$ & $(20.342)$ & $(13.935)$ & $(25.908)$ \\
\hline Rating $=7$ & - & - & $\begin{array}{c}56.068 * * * \\
(11.028)\end{array}$ & $\begin{array}{c}79.496 * * * \\
(12.103)\end{array}$ & - & - & - & - & - \\
\hline Rating $=8$ & - & - & $\begin{array}{c}60.999 * * * \\
(17.773)\end{array}$ & $\begin{array}{c}68.984 * * * \\
(23.553)\end{array}$ & - & - & - & - & - \\
\hline \multirow[t]{2}{*}{ AMOUNT } & $-7.044 *$ & $8.599 * * *$ & -1.983 & $9.060 * * *$ & -5.125 & 5.591 & 2.040 & 3.309 & $10.186^{* *}$ \\
\hline & $(3.980)$ & $(3.137)$ & $(3.835)$ & $(3.098)$ & $(4.336)$ & $(3.742)$ & $(5.618)$ & $(3.705)$ & $(4.180)$ \\
\hline \multirow[t]{2}{*}{ MATU } & $0.583 * * *$ & $2.047 * * *$ & $0.775^{* * *}$ & $2.227 * * *$ & $0.525 * * *$ & $2.112 * * *$ & $0.709 * * *$ & $1.546^{* * *}$ & 1.248 \\
\hline & $(0.192)$ & $(0.586)$ & $(0.198)$ & $(0.614)$ & $(0.198)$ & $(0.665)$ & $(0.262)$ & $(0.456)$ & $(0.892)$ \\
\hline \multirow[t]{2}{*}{ PUBLIC } & $-36.098 * * *$ & $-49.351 * * *$ & - & _ & $-41.306 * * *$ & $-64.311 * * *$ & -14.041 & $-20.047 * * *$ & $-57.797 * * *$ \\
\hline & (8.239) & (6.95) & & & $(9.204)$ & $(10.665)$ & $(10.403)$ & $(7.401)$ & $(9.321)$ \\
\hline \multirow[t]{2}{*}{ TA } & $-24.255 * *$ & 1.640 & - & _ & $-32.798 * *$ & 23.842 & -14.433 & -14.657 & 0.036 \\
\hline & $(10.613)$ & (11.914) & & & $(12.711)$ & $(15.673)$ & (12.748) & (14.103) & (15.339) \\
\hline \multirow[t]{2}{*}{ UK } & $19.150 * *$ & 3.815 & $19.325^{* *}$ & -0.495 & $18.589^{*}$ & 7.915 & $27.886^{* *}$ & $27.451 * * *$ & -1.528 \\
\hline & $(9.217)$ & $(7.915)$ & $(9.196)$ & $(7.755)$ & $(10.274)$ & (11.075) & (12.494) & $(9.264)$ & $(10.561)$ \\
\hline \multirow[t]{2}{*}{ Constant } & $153.176 * * *$ & 6.327 & $82.157 * * *$ & -28.204 & $151.118 * * *$ & 7.932 & $124.190 * * *$ & -10.621 & 1.742 \\
\hline & $(28.842)$ & $(21.794)$ & $(28.916)$ & $(22.980)$ & $(31.245)$ & $(26.993)$ & (33.422) & $(23.046)$ & $(29.402)$ \\
\hline $\mathrm{N}$ & 146 & 144 & 146 & 144 & 133 & 108 & 100 & 92 & 98 \\
\hline $\mathrm{R}^{2}$ & 0.764 & 0.755 & 0.747 & 0.751 & 0.754 & 0.781 & 0.740 & 0.702 & 0.686 \\
\hline Adjusted $\mathrm{R}^{2}$ & 0.712 & 0.705 & 0.692 & 0.700 & 0.694 & 0.718 & 0.655 & 0.606 & 0.585 \\
\hline $\mathrm{Fa}$ & $14.676^{* * *}$ & $14.937 * * *$ & $13.517 * * *$ & $14.944 * * *$ & $12.508 * * *$ & $12.357 * * *$ & $8.766 * * *$ & $7.293 * * *$ & 6.825 \\
\hline $\mathrm{Fb}$ & 1.868 & $2.952 * *$ & $5.943 * * *$ & $6.828 * * *$ & $2.170 *$ & $2.845 * *$ & 1.712 & $2.902 * *$ & 1.084 \\
\hline $\mathrm{Fc}$ & $2.047 *$ & $5.339 * * *$ & - & - & - & - & 1.315 & $3.426 * * *$ & $2.325 * *$ \\
\hline
\end{tabular}
the null hypothesis that the coefficients on the subset of rating dummy variables used to proxy bank risk jointly equal zero. Fc as Fb but restricted to the subsamples of private banks only. 
Table 9 - Regression results: FII and MBFS separate sub-samples

\begin{tabular}{|c|c|c|c|c|}
\hline & $\begin{array}{c}\text { FII } \\
\text { Total available } \\
\text { (1) }\end{array}$ & $\begin{array}{c}\text { MBFS } \\
\text { Total available } \\
\text { (2) }\end{array}$ & $\begin{array}{c}\text { FII } \\
\text { Same issues only } \\
(3)\end{array}$ & $\begin{array}{c}\text { MBFS } \\
\text { Same issues only } \\
(4)\end{array}$ \\
\hline Rating $=2$ & $\begin{array}{c}7.579 \\
(10.069)\end{array}$ & $\begin{array}{c}4.872 \\
(5.036)\end{array}$ & $\begin{array}{c}0.648 \\
(10.567)\end{array}$ & $\begin{array}{l}6.990 * \\
(4.022)\end{array}$ \\
\hline Rating $=3$ & $\begin{array}{l}14.681 \\
(9.614)\end{array}$ & $\begin{array}{c}14.450 * * \\
(6.134)\end{array}$ & $\begin{array}{c}10.299 \\
(10.085)\end{array}$ & $\begin{array}{c}16.985^{* * * *} \\
(4.808)\end{array}$ \\
\hline Rating $=4$ & $\begin{array}{c}23.811^{* *} \\
(10.425)\end{array}$ & $\begin{array}{c}32.615^{* * * *} \\
(7.055)\end{array}$ & $\begin{array}{l}17.654 * \\
(10.157)\end{array}$ & $\begin{array}{c}25.747 \text { **** } \\
(6.252)\end{array}$ \\
\hline Rating $=5$ & $\begin{array}{c}31.537 * * * \\
(11.447)\end{array}$ & $\begin{array}{c}38.681 * * * \\
(7.022)\end{array}$ & $\begin{array}{l}20.767 * \\
(11.792)\end{array}$ & $\begin{array}{c}36.270 \text { *** } \\
(6.487)\end{array}$ \\
\hline Rating $=6$ & $\begin{array}{c}34.051 * * \\
(15.057)\end{array}$ & $\begin{array}{c}27.668 \text { **** } \\
(9.982)\end{array}$ & $\begin{array}{c}28.255^{* *} \\
(14.182)\end{array}$ & $\begin{array}{c}33.020^{* * * * *} \\
(8.259)\end{array}$ \\
\hline AMOUNT & $\begin{array}{c}3.501 \\
(2.413)\end{array}$ & $\begin{array}{c}8.408 * * * \\
(2.807)\end{array}$ & $\begin{array}{c}6.374 * * * \\
(2.367)\end{array}$ & $\begin{array}{c}8.074 * * * \\
(2.192)\end{array}$ \\
\hline MATU & $\begin{array}{c}0.851 * * * \\
(0.191)\end{array}$ & $\begin{array}{c}1.020 * * * \\
(0.214)\end{array}$ & $\begin{array}{c}2.204 * * * \\
(0.348)\end{array}$ & $\begin{array}{c}2.372 * * * \\
(0.323)\end{array}$ \\
\hline DFL & $\begin{array}{c}3.957 \\
(9.525)\end{array}$ & $\begin{array}{c}16.012 \\
(11.207)\end{array}$ & $\begin{array}{l}13.286 \\
(9.543)\end{array}$ & $\begin{array}{l}15.524^{*} \\
(8.866)\end{array}$ \\
\hline EURO & $\begin{array}{c}4.762 \\
(8.892)\end{array}$ & $\begin{array}{c}5.615 \\
(9.751)\end{array}$ & $\begin{array}{c}6.388 \\
(8.042)\end{array}$ & $\begin{array}{c}7.016 \\
(7.507)\end{array}$ \\
\hline FFR & $\begin{array}{c}3.099 \\
(10.051)\end{array}$ & $\begin{array}{c}4.229 \\
(11.165)\end{array}$ & $\begin{array}{l}10.293 \\
(9.325)\end{array}$ & $\begin{array}{c}5.924 \\
(8.899)\end{array}$ \\
\hline STG & $\begin{array}{c}30.197 * * * \\
(9.520)\end{array}$ & $\begin{array}{c}25.134 * * \\
(10.691)\end{array}$ & $\begin{array}{c}21.122^{* *} * \\
(8.970)\end{array}$ & $\begin{array}{c}20.340 * * \\
(8.323)\end{array}$ \\
\hline USD & $\begin{array}{c}31.828 * * * \\
(9.373)\end{array}$ & $\begin{array}{c}32.458 * * * * \\
(10.251)\end{array}$ & $\begin{array}{c}32.480 * * * \\
(8.804)\end{array}$ & $\begin{array}{c}30.379 * * * * \\
(8.161)\end{array}$ \\
\hline DEM & $\begin{array}{c}12.080 \\
(10.945)\end{array}$ & $\begin{array}{l}19.641^{*} \\
(11.018)\end{array}$ & $\begin{array}{c}21.916 * * \\
(10.047)\end{array}$ & $\begin{array}{c}22.767 * * \\
(9.134)\end{array}$ \\
\hline PUBLIC & $\begin{array}{c}-37.566 * * * \\
(4.787)\end{array}$ & $\begin{array}{c}-43.885^{* * *} \\
(5.418)\end{array}$ & $\begin{array}{c}-37.437 * * * \\
(4.557)\end{array}$ & $\begin{array}{c}-44.137 * * * \\
(4.695)\end{array}$ \\
\hline TA & $\begin{array}{c}-16.142^{* *} \\
(7.519)\end{array}$ & $\begin{array}{l}-6.346 \\
(8.650)\end{array}$ & $\begin{array}{l}-12.110 \\
(7.654)\end{array}$ & $\begin{array}{c}2.918 \\
(7.629)\end{array}$ \\
\hline GER & $\begin{array}{c}1.558 \\
(5.890)\end{array}$ & $\begin{array}{c}3.937 \\
(6.247)\end{array}$ & $\begin{array}{c}4.413 \\
(5.746)\end{array}$ & $\begin{array}{l}-1.662 \\
(5.216)\end{array}$ \\
\hline SPA & $\begin{array}{c}6.105 \\
(7.046)\end{array}$ & $\begin{array}{c}1.729 \\
(7.092)\end{array}$ & $\begin{array}{c}0.716 \\
(6.371)\end{array}$ & $\begin{array}{l}-3.023 \\
(6.066)\end{array}$ \\
\hline FRA & $\begin{array}{l}-4.634 \\
(6.945)\end{array}$ & $\begin{array}{c}2.962 \\
(7.447)\end{array}$ & $\begin{array}{l}-7.617 \\
(6.915)\end{array}$ & $\begin{array}{l}-9.780 \\
(6.156)\end{array}$ \\
\hline UK & $\begin{array}{c}13.265^{* * *} \\
(5.805)\end{array}$ & $\begin{array}{c}7.098 \\
(6.465)\end{array}$ & $\begin{array}{c}2.563 \\
(5.503)\end{array}$ & $\begin{array}{l}-1.882 \\
(5.108)\end{array}$ \\
\hline NET & $\begin{array}{l}-2.417 \\
(6.665)\end{array}$ & $\begin{array}{l}-3.901 \\
(7.388)\end{array}$ & $\begin{array}{l}-9.124 \\
(6.409)\end{array}$ & $\begin{array}{l}-7.115 \\
(6.053)\end{array}$ \\
\hline SWI & $\begin{array}{l}-11.670 \\
(9.899)\end{array}$ & $\begin{array}{l}-7.515 \\
(7.373)\end{array}$ & $\begin{array}{c}-6.860 \\
(10.732)\end{array}$ & $\begin{array}{c}-17.299 * \\
(9.980)\end{array}$ \\
\hline Constant & $\begin{array}{c}82.286 * * * * \\
(19.612)\end{array}$ & $\begin{array}{c}24.166 \\
(18.473) \\
\end{array}$ & $\begin{array}{c}37.328 * * \\
(17.741)\end{array}$ & $\begin{array}{c}16.127 \\
(15.124)\end{array}$ \\
\hline $\mathrm{N}$ & 236 & 219 & 165 & 165 \\
\hline $\mathrm{R}^{2}$ & 0.756 & 0.711 & 0.803 & 0.831 \\
\hline Adjusted $\mathrm{R}^{2}$ & 0.720 & 0.668 & 0.767 & 0.800 \\
\hline $\mathrm{Fa}$ & $21.143 * * *$ & $16.567 * * *$ & $22.261 * * *$ & $26.888^{* * *}$ \\
\hline $\mathrm{Fb}$ & $2.833^{* *}$ & $3.240 * * *$ & $2.389 * *$ & $3.014 * *$ \\
\hline
\end{tabular}

***,**, and * indicate statistical significance at the $1 \%, 5 \%$ and $10 \%$ level, respectively. Standard errors in parenthesis $\mathrm{Fb}$ denotes the calculated F-statistic for the null hypothesis that the coefficients on the subset of rating dummy variables jointly equal zero. 


\section{Appendix 1 \\ Moody's Bank Financial Strength Definitions}

According to Moody’s, “Bank Financial Strength Ratings represent Moody’s opinion of a bank's intrinsic safety and soundness and, as such, exclude certain credit risks and credit support elements which are addressed by Moody's traditional debt and deposit ratings. Unlike Moody's traditional debt ratings, BFSR do not address the probability of timely payment. Instead, BFSR can be understood as a measure of the likelihood that a bank will require assistance from third parties such as its owners, its industry groups, or official institutions. BFSR do not take into account the probability that the bank will receive such external support, nor do they address risks arising from sovereign actions which may interfere with a bank's ability to honor its domestic or foreign currency obligations. Factors considered in the assignment of BFSR include bank-specific elements such as financial fundamentals, franchise value, and business and asset diversification. Although BFSR exclude the external factors specified above, they do take into account other risk factors in the bank's operating environment, including the strength and prospective performance of the economy, as well as the structure and relative fragility of the financial system, and the quality of banking regulation and supervision".

\begin{tabular}{|c|l||}
\hline $\begin{array}{c}\text { Rating } \\
\text { class }\end{array}$ & \multicolumn{1}{|c||}{ Definition } \\
\hline $\mathbf{A}$ & $\begin{array}{l}\text { Banks with exceptional financial strength. Typically, they will be major institutions with highly valuable and defensible } \\
\text { business franchises, strong financial fundamentals, and a very attractive and stable operating environment }\end{array}$ \\
\hline $\mathbf{B}$ & $\begin{array}{l}\text { Banks with strong intrinsic financial strength. Typically, they will be important institutions with valuable and defensible } \\
\text { business franchises, good financial fundamentals, and an attractive and stable operating environment }\end{array}$ \\
\hline $\mathbf{C}$ & $\begin{array}{l}\text { Banks with good financial strength. Typically, they will be institutions with valuable and defensible business franchises. } \\
\text { These banks will demonstrate either acceptable financial fundamentals within a stable operating environment or better than } \\
\text { average financial fundamentals with an unstable operating environment }\end{array}$ \\
\hline $\mathbf{D}$ & $\begin{array}{l}\text { Banks that possess adequate financial strength, but may be limited by one or more of the following factors: a vulnerable or } \\
\text { developing business franchise; weak financial fundamentals; or an unstable operating environment }\end{array}$ \\
\hline $\mathbf{E}$ & $\begin{array}{l}\text { Banks with very weak intrinsic financial strength, requiring periodic outside support or suggesting an eventual need for } \\
\text { outside assistance. Such institutions may be limited by one or more of the following factors: a business franchise of } \\
\text { questionable value; financial fundamentals that are seriously deficient in one or more respects; or a highly unstable operating } \\
\text { environment }\end{array}$ \\
\hline \hline
\end{tabular}

In addition, four more gradations (notches) among these five main rating classes are used by Moody's: B+, C+, D+, E+. 


\section{Appendix 2}

\section{Fitch IBCA Individual Rating Definitions}

According to FitchIBCA, the "Individual Rating attempts to assess how a bank would be viewed if it were entirely independent and could not rely on support from state authorities or its owners. Thus the Individual Rating permits an evaluation divorced entirely from consideration of support".

\begin{tabular}{|c|l||}
\hline $\begin{array}{c}\text { Rating } \\
\text { class }\end{array}$ & \multicolumn{1}{|c|}{ Definition } \\
\hline A & A bank of impeccable financial condition. With a consistent record of above average performance \\
\hline B & $\begin{array}{l}\text { A bank with a sound risk profile and without significant problems. The bank's performance has generally been in line with } \\
\text { or better than its peers }\end{array}$ \\
\hline C & $\begin{array}{l}\text { A bank which has an adequate risk profile but possesses one or more troublesome aspects, giving rise to the possibility of } \\
\text { risk developing, or which has generally failed to perform in line with its peers }\end{array}$ \\
\hline D & $\begin{array}{l}\text { A bank which is currently underperforming in some notable manner. Its financial condition is likely to be below average and } \\
\text { its profitability poor. The bank has the capability to recover using its own resources, but this is likely to take some time }\end{array}$ \\
\hline E & A bank with very serious problems which either requires or is likely to require external support \\
\hline \hline
\end{tabular}

In addition, four more gradations (notches) among these five main rating classes are used by FitchIBCA: A/B, B/C, C/D, D/E.

Appendix 3

Ratings Scales

\begin{tabular}{|c|c|c|c|c|c|c|c|c|c|c|}
\hline NUMBER & 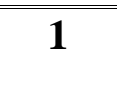 & 2 & 3 & 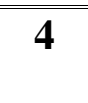 & 5 & 6 & 7 & 8 & 9 & 10 \\
\hline MOODY's ISSUE AND ISSUER & Aaa & Aa1 & Aa2 & $\mathrm{Aa3}$ & A1 & $\mathrm{A} 2$ & A3 & Baa1 & Baa2 & Baa3 \\
\hline STANDARD \& POORS ISSUE AND ISSUER & AAA & $\mathrm{AA}+$ & $\mathrm{AA}$ & AA- & A+ & A & A- & $\mathrm{BBB}+$ & BBB & BBB- \\
\hline MOODY's FINANCIAL STRENGTH (MBFS) & $\mathrm{A}$ & $\mathrm{B}+$ & $\mathrm{B}$ & $\mathrm{C}+$ & $\mathrm{C}$ & $\mathrm{D}+$ & $\mathrm{D}$ & E+ & $\mathrm{E}$ & - \\
\hline FITCH IBCA INDIVIDUAL (FII) & A & $\mathrm{A} / \mathrm{B}$ & $\mathrm{B}$ & $\mathrm{B} / \mathrm{C}$ & $\mathrm{C}$ & $\mathrm{C} / \mathrm{D}$ & $\mathrm{D}$ & $\mathrm{D} / \mathrm{E}$ & $E$ & - \\
\hline
\end{tabular}




\section{Appendix 4}

Moody's, S\&P and Fitch IBCA ratings sample availability and concordance

\begin{tabular}{|c|c|c|c|c|c|c|}
\hline & \multicolumn{2}{|c|}{ ISSUE } & \multicolumn{4}{|c|}{ ISSUER } \\
\hline & Moody's & $\mathrm{S} \& \mathrm{P}$ & Moody's & $\mathrm{S} \& \mathrm{P}$ & MBFS & FII \\
\hline Total Available & 240 & 117 & & & 219 & 236 \\
\hline Common & \multicolumn{2}{|c|}{67} & \multicolumn{2}{|c|}{151} & \multicolumn{2}{|c|}{165} \\
\hline & Number & $\%$ & Number & $\%$ & Number & $\%$ \\
\hline Equal & 24 & 35.82 & 51 & 33.77 & 61 & 36.97 \\
\hline Different by 1 notch & 35 & 52.24 & 90 & 59.60 & 93 & 56.36 \\
\hline Different by 2 notches & 7 & 10.45 & 7 & 4.64 & 11 & 6.67 \\
\hline Different by 3 notches & 1 & 1.49 & 3 & 1.99 & 0 & 0.00 \\
\hline Total & 67 & 100 & 151 & 100 & 165 & 100 \\
\hline
\end{tabular}

\section{Appendix 5}

\section{Moody's, S\&P and Fitch IBCA ratings sample Pearson correlation coefficients}

\begin{tabular}{||l|c|c|c||}
\hline \hline & $\begin{array}{c}\text { Issue Moody's-S\&P } \\
\text { versus } \\
\text { Issuer MBFS/FII }\end{array}$ & $\begin{array}{c}\text { Issuer Moody's-S\&P } \\
\text { versus } \\
\text { Issuer MBFS/FII }\end{array}$ & $\begin{array}{c}\text { Issue Moody's-S\&P } \\
\text { versus } \\
\text { Issuer Moody's-S\&P }\end{array}$ \\
\hline Germany & -0.034 & 0.121 & 0.913 \\
\hline France & 0.810 & 0.824 & 0.919 \\
\hline Netherland & 0.841 & 0.899 & 0.920 \\
\hline Spain & 0.893 & 0.926 & 0.905 \\
\hline Switzerland & 0.853 & 0.904 & 0.926 \\
\hline Great Britain & 0.713 & 0.799 & 0.848 \\
\hline Others & 0.113 & 0.198 & 0.907 \\
\hline Total Sample & 0.316 & 0.437 & 0.918 \\
\hline
\end{tabular}

